\title{
Abnormal Morphology of Distal Tubular Epithelial Cells Is Regulated by Genetic Factors Derived from Mouse Chromosome 12
}

Osamu Ichii, ${ }^{*}$ Teppei Nakamura, ${ }^{\dagger \dagger}$ Taro Horino, ${ }^{\ddagger}$ Akira Yabuki, ${ }^{\S}$ Yaser H.A. Elewa, ${ }^{* \top}$ and Yasuhiro Kon*

\begin{abstract}
From the Laboratory of Anatomy, * Department of Basic Veterinary Sciences, Faculty of Veterinary Medicine, Hokkaido University, Sapporo, Japan; the Section of Biological Science, ${ }^{\dagger}$ Chitose Laboratory, Japan Food Research Laboratories, Chitose, Japan; the Department of Endocrinology, Metabolism and Nephrology, ${ }^{\ddagger}$ Kochi Medical School, Kochi University, Nankoku, Japan; the Laboratory of Clinical Pathology, ${ }^{\S}$ Joint Faculty of Veterinary Medicine, Kagoshima University, Kagoshima, Japan; and the Department of Histology and Cytology, "Faculty of Veterinary Medicine, Zagazig University, Zagazig, Egypt
\end{abstract}

Accepted for publication

May 22, 2018.

Address correspondence to Osamu Ichii, D.V.M., Ph.D., Laboratory of Anatomy, Department of Basic Veterinary Sciences, Faculty of Veterinary Medicine, Hokkaido University, Kita 18, Nishi 9, Kita-ku, Sapporo, Hokkaido 060-0818, Japan. E-mail: ichi-o@vetmed. hokudai.ac.jp.

\begin{abstract}
The distal tubule (DT) helps regulate blood pressure and electrolytes. We describe a novel, autosomal recessive, morphofunctional DT abnormality in inbred mice evident as columnar alternations and agerelated cystic changes. This abnormality developed in both sexes of $D B A / 2 \mathrm{Cr}$. Similar phenotypes were observed in $\mathrm{A} / \mathrm{J}, \mathrm{C} 3 \mathrm{H} / \mathrm{He}, \mathrm{DBA} / 1 \mathrm{~J}$, and $\mathrm{FVB} / \mathrm{N}$ strains, but not in $\mathrm{AKR} / \mathrm{N}, \mathrm{BALB} / \mathrm{C}$, or $\mathrm{C} 57 \mathrm{BL} / 6 \mathrm{~N}$ strains. In $\mathrm{DBA} / 2 \mathrm{Cr}$, abnormal DT localized to straight and convoluted segments and showed IL-36 $\alpha$ DT injury marker expression. However, DT epithelial proliferation, examined by bromodeoxyuridine incorporation, was not remarkably altered with the progression of abnormality. Abnormal DT epithelial cells in DBA/2Cr displayed elongated primary cilia, loose intercellular adhesions, and numerous vesicles with altered localization of $\mathrm{CD} 9, \mathrm{Na}^{+} / \mathrm{K}^{+}$ATPase, and E-cadherin, indicating altered cell function, adhesion, and polarity. DBA/2Cr-type D12Mit182-D12Mit83 was identified as a candidate locus designated DBA/2 renal cyst (drecy). Within drecy, the gene regulated by estrogen in breast cancer protein (Greb1) transcript variant 2 was significantly up-regulated in DBA/2Cr kidney versus $\mathrm{C57BL} / 6 \mathrm{~N}$. Greb1 localized to DT cytoplasm in C57BL/6 and to cytoplasm and nucleus in DBA/2Cr. Greb1-overexpressing M-1 kidney cells showed an altered epithelial-mesenchyme phenotype. B6.D2-(D12Mit182-D12Mit83) congenic mice carrying drecy did not show DT abnormalities, whereas DBA/2Cr $\times$ B6.D2-(D12Mit182-D12Mit83) mice did. Identification of this novel DT abnormality regulated by a DBA $/ 2 \mathrm{Cr}$ mouse chromosome 12 -derived locus and additional genetic factors improve the understanding of DT pathogenesis. (Am J Pathol 2018, 188: 2120-2138; https://doi.org/10.1016/j.ajpath.2018.05.011)
\end{abstract}

The mammalian kidney has crucial roles in regulating blood filtration and reabsorption, as well as in regulating systemic blood pressure and electrolyte balance. To support these renal functions, nephrons and collecting ducts-and the cells that comprise those structures-develop highly specialized morphologies to perform their specialized functions (morphofunction). Each renal tubule segment, including the proximal tubule (PT) and distal tubule (DT), has unique molecular expression patterns corresponding to its unique function(s). Quantitative or qualitative alterations of those patterns can lead to local tubular lesions with abnormal morphologies, such as atrophy and dilations.
Renal disease phenotypes often reflect the role of the mutated gene. For instance, in humans, polycystin 1 $(P K D 1), P K D 2$, and fibrocystin/polyductin (PKHD1) regulate the functions of primary cilia. When mutated, they cause the PT-derived cysts found in autosomal dominant polycystic kidney disease (PKD) or collecting duct-derived cysts found in autosomal recessive PKD. ${ }^{1}$ Furthermore,

Supported in part by Inamori Foundation grants, Kazato Research grants, and JSPS KAKENHI grants 13J00961, 15K14873, and 18H02331.

Disclosures: None declared. 
nephronophthisis (NPH) is characterized by tubulointerstitial nephritis, corticomedullary cystic lesions, and progression to end-stage renal disease before 30 years of age in humans. The pathologic contributions of known or unknown NPH-related genes associated with cilium function have been suggested in NPH pathogenesis., ${ }^{2,3}$

Although candidate gene mutations strongly affect kidney disease phenotypes, the genetic background is also an important contributing factor in both humans and animals. Susceptibility to kidney diseases differs among genetic backgrounds, including race and ethnicity. Polymorphisms of IL-6 receptor (IL6R), ${ }^{4}$ apolipoprotein L1 (APOL1), ${ }^{5}$ and transforming growth factor- $\beta 1(T G F B 1)^{6}$ are associated with the risk of human cystic kidney disease. Susceptibility to kidney diseases also varies among experimental mouse models. For example, the $\mathrm{kat}^{2 J}$ allele on chromosome (Chr) 8 causes late-onset PKD and anemia, and this phenotype is modified by the genetic loci on mouse $\mathrm{Chr} 1,2$, and 19 . $^{7}$ PKD model mice ( $p c y$ mice) carry a mutant allele of nephronophthisis 3 (Nphp3) and present with cystic kidney disease, ${ }^{3}$ but the severity of the phenotype is strongly affected by their genetic background. For example, $p c y$ mice on a DBA/2 background (DBA/2-type $p c y$ mice) show a more severe phenotype than $p c y$ mice on a C57BL/6 background. ${ }^{8}$ In addition, whole-genome analysis of DBA/ 2-type pcy mice has identified two major loci, D4Mit111 and D16Mitl, associated with renal cyst progression. ${ }^{9}$ The presence of the DBA/2 Chr 10 also modifies the phenotypes of juvenile cystic kidney (jck) mice. ${ }^{10}$

The DBA/2 mouse strain has been globally used in genetic and phenotypic comparisons with other inbred strains. The DBA/2 mouse genome contains several loci associated with cystic kidney diseases, as described above. Several other kidney-related phenotypes are also associated with the DBA/2type genome. They include the appearance of giant lysosomes in the PTs of DBA/2 mice, ${ }^{11}$ higher albumin excretion in the urine of DBA/2 mice than in the urine of C57BL/6 mice, ${ }^{12}$ the development of ureteritis-hydronephrosis in the progenies between C57BL/6 mice and DBA/2 mice, ${ }^{13}$ and higher kidney calcium concentrations in DBA/2 mice than in C57BL/6 mice. ${ }^{14}$ In addition, streptozotocin-induced diabetic nephropathy is more severe in DBA/2 mice than in other inbred strains, including C57BL/6 mice. ${ }^{15}$ Concerning systemic phenotypes, DBA/2 mice also show higher susceptibility of experimental systemic lupus erythematosus by the immunization with the human monoclonal anti-DNA antibody compared with C57BL/6 mice. ${ }^{16}$

Expanding on these previously identified phenotypes, we present that DBA/2Cr (D2Cr) mice frequently developed a severe DT abnormality characterized by aging-related renal cystic changes with altered molecular expression associated with altered DT morphofunction. Interestingly, although Chr 12 regulated the DT phenotype in D2Cr mice, we were unable to identify any cilium-associated genes within this candidate locus. The DT is a relatively short segment compared with the PT, but is a crucial regulation center for blood pressure and electrolytes. Therefore, this novel result will be important for the full understanding of renal pathogenesis and dysfunction, and the susceptibility to kidney diseases, especially those regulated by the genetic factors associated with the DT abnormality.

\section{Materials and Methods}

\section{Ethics Statement}

Animal experimentation was approved by the Institutional Animal Care and Use Committee of the Graduate School of Veterinary Medicine, Hokkaido University (Sapporo, Japan; approvals 08-0180, 09-0129, 11-0033, 13-0031, 13-0032, and 16-0124). Investigators adhered to the Guide for the Care and Use of Laboratory Animals of Hokkaido University, Graduate School of Veterinary Medicine (approved by the Association for the Assessment and Accreditation of Laboratory Animal Care International).

\section{Mice and Tissue Preparation}

A/J, AKR/N, BALB/c, C57BL/6N (B6N), C3H/He, DBA/ $1 \mathrm{~J}$, and D2Cr mice were purchased from Japan SLC Inc. (Shizuoka, Japan). FVB/N mice were purchased from CREA Japan Inc. (Tokyo, Japan). Some D2Cr mice were injected intraperitoneally with bromodeoxyuridine (BrdU; $100 \mathrm{mg} / \mathrm{kg}$ ) 2 hours before sampling. Kidneys were collected and fixed in either 4\% paraformaldehyde for histologic analysis or $2.5 \%$ glutaraldehyde for electron microscopy analysis. A part of each kidney was stocked in RNA later (Thermo Fisher Scientific, Waltham, MA) until gene expression analysis.

\section{Histochemical Analysis}

Paraffin-embedded kidney sections were stained by periodic acid-Schiff. Other sections were analyzed by immunohistochemistry or immunofluorescence using the primary antibodies listed in Table 1, as described previously, ${ }^{17}$ and evaluated for expression of the following proteins: uromodulin, calbindin D28k, IL-1 family member 6 (IL-1F6/IL$36 \alpha$ ), E-cadherin, claudin $3, \mathrm{Na}^{+} / \mathrm{K}^{+}$ATPase, vimentin, gene regulated by estrogen in breast cancer protein (Greb1), and synaptopodin. Whole-mount immunohistochemical analysis was performed to detect IL-1F6/IL-36 $\alpha^{+}$DTs, as described previously, ${ }^{18}$ by fluorescence microscopy using a model BZ-X710 microscope (Keyence, Osaka, Japan).

\section{Electron Microscopy}

Glutaraldehyde-fixed kidneys were postfixed with $1 \% \mathrm{OsO}_{4}$ in $0.1 \mathrm{~mol} / \mathrm{L}$ phosphate buffer for 2 hours. Specimens were then dehydrated with an ascending series of alcohol concentrations and embedded in epoxy resin (Quetol 812 Mixture; Nisshin EM, Tokyo, Japan). The epoxy blocks were cut at a thickness of 
Table 1 Antibodies Used in This Study

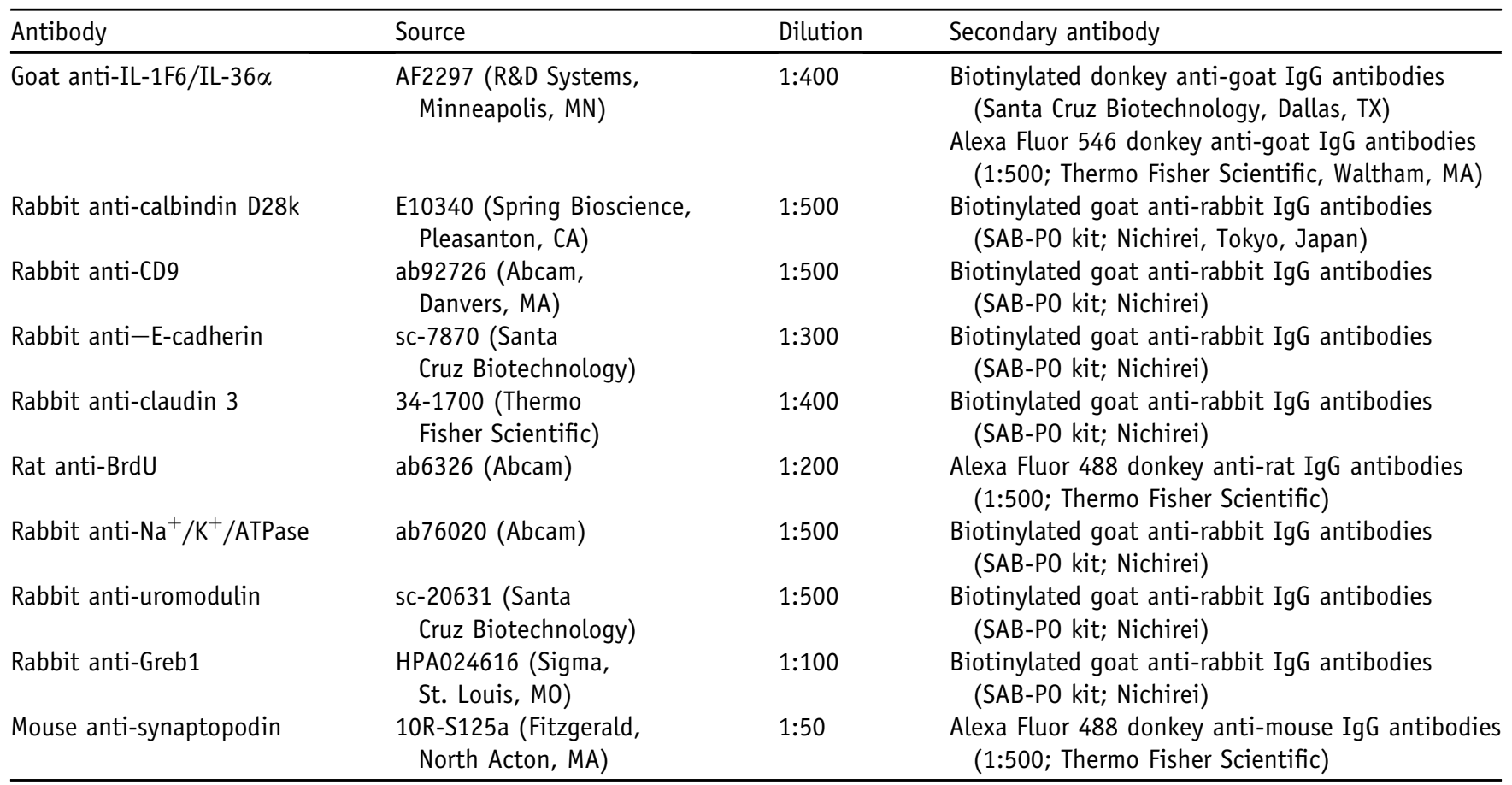

Antigen retrieval: $20 \mathrm{mmol} / \mathrm{L}$ Tris- $\mathrm{HCl}, 105^{\circ} \mathrm{C}, 15$ to 20 minutes.

BrdU, bromodeoxyuridine; Greb1, gene regulated by estrogen in breast cancer protein; IL-1F6, IL-1 family member 6.

$60 \mathrm{~nm}$, stained with uranyl acetate and lead citrate, and then examined via transmission electron microscopy using a JEM1210 microscope (JEOL, Tokyo, Japan). For scanning electron microscopy, glutaraldehyde-fixed kidneys were treated with tannic acid and postfixed with $1 \% \mathrm{OsO}_{4}$ in $0.1 \mathrm{~mol} / \mathrm{L}$ phosphate buffer for 1 hour. The specimens were dehydrated with graded alcohol, transferred to 3-methylbutyl acetate, and finally dried using a model HCP-2 critical point dryer (Hitachi, Tokyo, Japan). Scanning electron microscopy was done using a model S-4100 microscope (Hitachi).

\section{Morphometric Analysis}

Histoplanimetry of DT abnormality was performed. For all DTs observed in the kidney section, DTs displaying an abnormality were enumerated on transverse kidney sections for each grade (0 to 5 ) of abnormality (Figure $1, \mathrm{~A}-\mathrm{F}$ ). The abnormalities were graded by comparison with normal DT features evident as in B6N mice (Figure 1A). Grade 1 (Figure 1B) features the presence of columnar epithelial cells in a DT. Grade 2 is characterized by slight dilation of the lumen (less than the glomerular size) with the columnar epithelial cells in a DT. Grade 3 (Figure 1C) features mild dilation of the lumen (approximately one to three times larger glomerular size) in a DT. Grade 4 (Figure 1D) features more severe dilation of lumen than in grade 3 in a DT. Finally, grade 5 (Figure 1E) is characterized by several grade 4 DT lesions in the same observation area. The DT abnormality score was calculated as follows:
$100 \times[$ (number of grade $0 \times 0)+($ number of grade $1 \times$ 1) + (number of grade $2 \times 2$ ) + (number of grade $3 \times$ $3)+($ number of grade $4 \times 4)+($ number of grade $5 \times 5)$ ].

The average value of the examined sections (at least four sections per mouse) was used as the DT damage score of each strain.

To examine cell proliferation, the ratio determined by the number of nuclei incorporating BrdU divided by the total number of nuclei in a DT was calculated. The correlation between the ratio and the index of DT size indicated by the number of total nuclei was analyzed in D2Cr mice. Similarly, by using Greb1-immunostained sections, the number of Greb1-positive nuclei was determined and divided by the total number of nuclei in a DT, and the percentage of Greb1positive nuclei was compared between $\mathrm{B} 6 \mathrm{~N}$ and $\mathrm{D} 2 \mathrm{Cr}$ mice.

To evaluate the alternation of cell heights and cilia lengths with the development of abnormal DTs in D2Cr mice, these dimensions were measured in periodic acid-Schiff-stained sections and scanning electron microscopy specimens, respectively. Cell height was defined as the shortest distance from the apical portion of the cell to the basement membrane. At the same time, the tubular lumen area was also measured as the index of DT size, and the correlation between cell height or cilia length and tubular lumen area was analyzed.

To evaluate the alternation of cell polarity in DTs of D2Cr mice, the localization of $\mathrm{Na}^{+} / \mathrm{K}^{+}$ATPase in DT epithelial cells was examined. Briefly, the immunohistochemical images for $\mathrm{Na}^{+} / \mathrm{K}^{+}$ATPase were obtained and converted to binary images using Adobe Photoshop software version 11.0.2 (San Jose, CA). The ratio of the positive intensity in the lateral side of cytoplasm to that in the basal side was examined by measuring the mean 

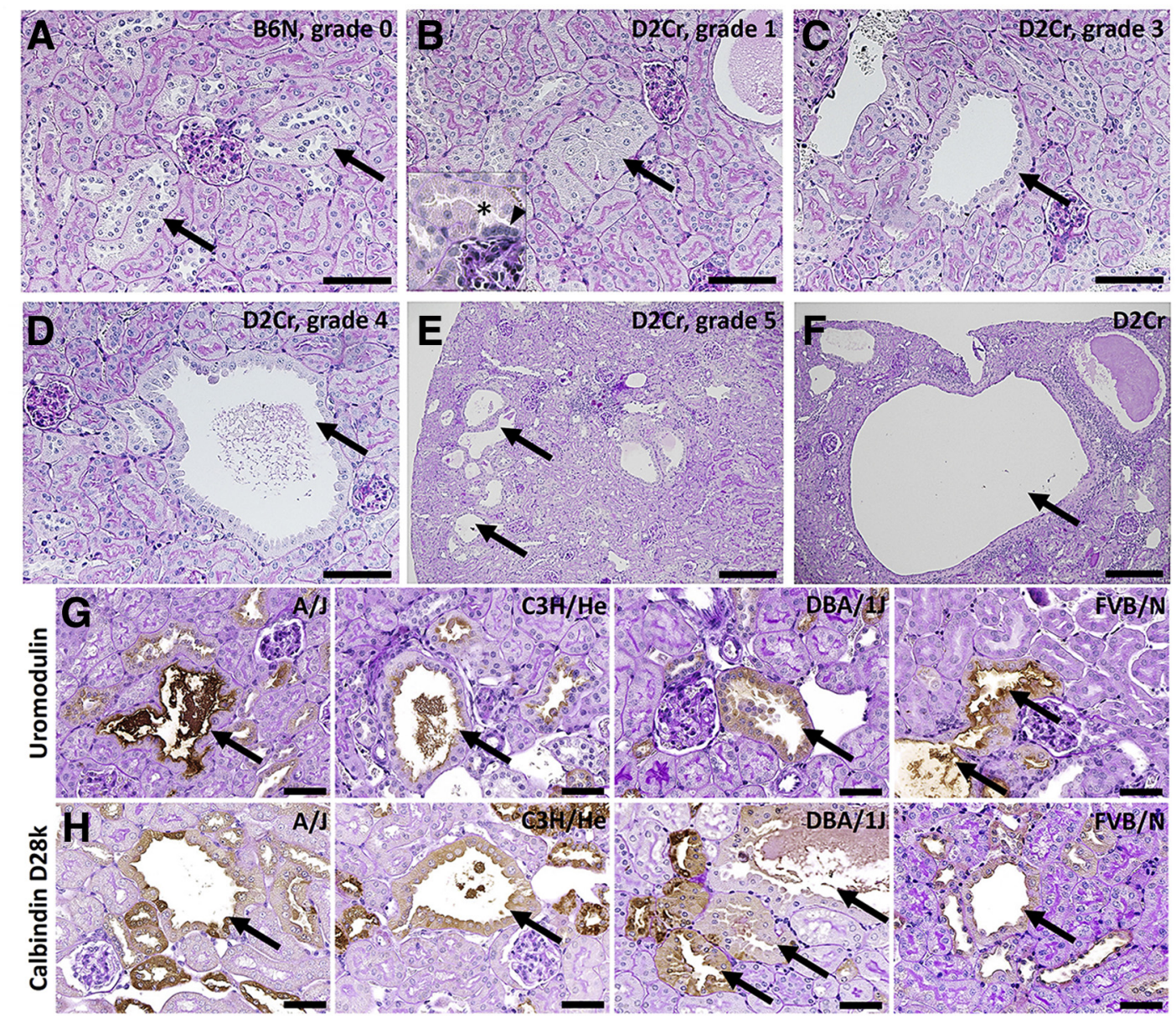

I
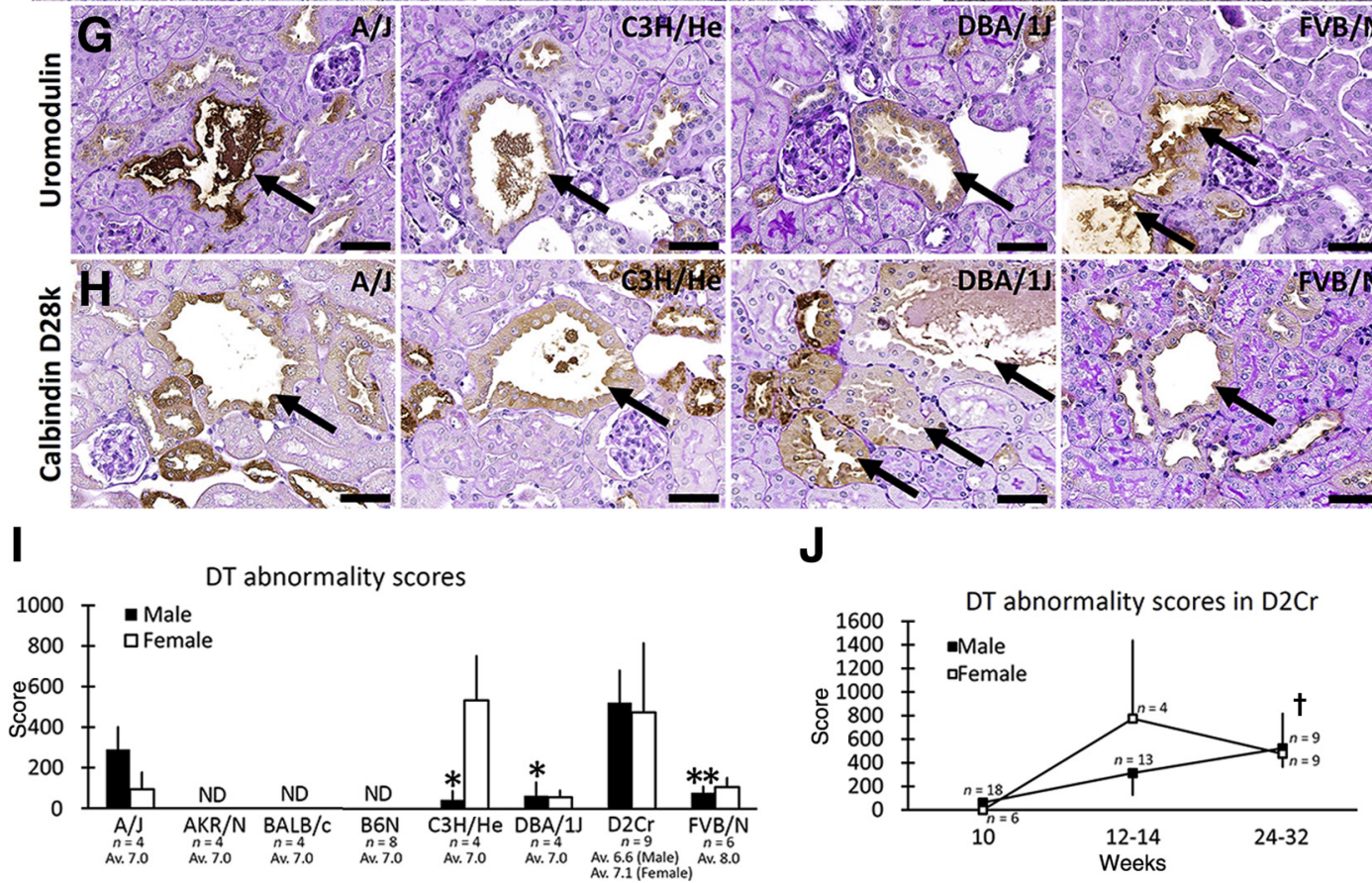

Figure 1 Abnormal distal tubule (DT) morphology in inbred mouse strains. A-F: Periodic acid-Schiff-stained kidney sections. A: Normal DT morphology is shown in a male C57BL/6N (B6N) mouse at 3 months (arrows). B: DT with columnar epithelial cells in a male DBA/2Cr (D2Cr) mouse at 3 months of age (arrow) indicates a histoplanimetry DT abnormality score of grade 1. Inset: The abnormal DT (asterisk), including macula densa (arrowhead). C: The DT lumen is dilated in a male D2Cr mouse at 8 months of age (arrow), indicating histoplanimetry abnormality score of grade 3. D: Cystic DT can be seen in a male D2Cr mouse at 8 months of age (arrow), for a histoplanimetry grade of 4. E: Several cystic DTs are visible in male D2Cr mice at 8 months of age (arrows), for a histoplanimetry grade of 5. F: Large cystic DTs occupy the renal cortex (arrow). G and H: Immunohistochemistry for the DT markers, uromodulin and calbindin D28k. Male A/J, female $\mathrm{C} 3 \mathrm{H} / \mathrm{He}$, male DBA/1J, and male FVB/N mice, aged 5 to 8 months, display DT abnormalities similar to D2Cr mice, and these tubules react positively for uromodulin and calbindin D28k (arrow). I: DT abnormality scores in inbred mice at 5 to 8 months of age. J: Time course of DT abnormality scores in D2Cr mice. Data are expressed as means \pm SEM (I and $\mathbf{J})$. ${ }^{*} P<0.05,{ }^{*} P<0.01$ comparing same-sex D2Cr mice; ${ }^{\dagger} P<0.05$ for the difference from the same sex at 10 weeks. Scale bars: $50 \mu \mathrm{m}(\mathbf{A}-\mathbf{C}, \mathbf{G}$, and $\mathbf{H}) ; 200 \mu \mathrm{m}(\mathbf{D}-\mathbf{F})$. Av, average age in months in the examined mice; ND, not detected.

gray value using ImageJ software version $1.51 \mathrm{j} 8(\mathrm{NIH}$, Bethesda, MD; http://imagej.nih.gov/ij).

\section{Genetic Analysis}

$(\mathrm{D} 2 \mathrm{Cr} \times \mathrm{B} 6 \mathrm{~N}) \mathrm{F}_{1},(\mathrm{~B} 6 \mathrm{~N} \times \mathrm{D} 2 \mathrm{Cr})\left(\mathrm{BDF}_{1}\right), \mathrm{BDF}_{1} \times \mathrm{D} 2 \mathrm{Cr}$ $(\mathrm{N} 2)$, and $\mathrm{BDF}_{1} \times \mathrm{BDF}_{1}\left(\mathrm{~F}_{2}\right)$ progeny mice were obtained from each mating. To explore the candidate locus for DT abnormality, linkage analysis was performed using genomic DNA obtained from $\mathrm{N} 2$ and $\mathrm{F}_{2}$ progeny (96 and 153 mice, respectively). The appearance of DT abnormality was defined as a phenotype trait, and the mouse genotype was examined by genotyping based on PCR for microsatellite markers (Table 2). PCR amplification products were electrophoresed in a $2 \%$ agarose gel and imaged under light-emitting diode illumination. Genotype-phenotype linkage was analyzed by 
Table 2 Primers Used in This Study

\begin{tabular}{|c|c|c|c|c|c|}
\hline Gene & Gene ID & Forward primer & Reverse primer & Size, bp & Application \\
\hline Actb & 11461 & $5^{\prime}-$ TCCTTCGTTGCCGGTCCACA-3' & $5^{\prime}-\mathrm{TGGGCCTCGTCACCCACATA-3^{ \prime }}$ & 196 & $\begin{array}{c}\text { Real-time PCR, } \\
\text { normalization }\end{array}$ \\
\hline Adam17 & 11491 & 5'-TGGCAAATGTGAGAAACGAG-3' & 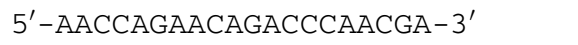 & 121 & Real-time PCR \\
\hline Asap2 & 211914 & $5^{\prime}-$ GGGAAACAAGGAGCATGGAAC- $3^{\prime}$ & $5^{\prime}-$ АСАСТTССТСТTCTGCCACAC-3' & 88 & Real-time PCR \\
\hline Atp $6 v 1 c 2$ & 68775 & $5^{\prime}$-GCGATATTGTCAGCAAGGAAG-3' & $5^{\prime}$-GGAAGAGAGTCACCGTGAAGAG-3' & 192 & Real-time PCR \\
\hline Cpsf3 & 54451 & 5'-TGAGAAGCGTGAAGAGCGAG-3' & $5^{\prime}$-GAGCAAAGACAGGAATGAGCC $-3^{\prime}$ & 92 & Real-time PCR \\
\hline Fam $84 a$ & 105005 & 5'-GATAGATCGGAACCGCAGTC-3' & 5'-TTGGTTGCCCATCAATGAC-3' & 172 & Real-time PCR \\
\hline Gapdh & 14433 & 5'-CCGCATCTTCTTGTGCAG-3' & 5'-TGCCGTGAGTGGAGTCATAC-3' & 199 & $\begin{array}{l}\text { Real-time PCR, } \\
\text { normalization }\end{array}$ \\
\hline Greb1 Tv1 & 268527 & 5'-GCGCGAGAGCTCCCATAAAG-3' & $5^{\prime}$-CTTGTGACCCGTGGCAGAT-3' & 89 & $\begin{array}{l}\text { RT-PCR, } \\
\text { real-time PCR }\end{array}$ \\
\hline Iah1 & 67732 & 5'-GGGTCATCCTTATCACGCCA-3' & $5^{\prime}$-TTCTGCATCAGGGTCCACAG-3' & 178 & Real-time PCR \\
\hline Itgb1bp1 & 16413 & 5'-TCTGGGCGTTTCTAAGTACGG-3' & 5'-CTTGCATCTGTGGTCTTGAGTG-3' & 156 & Real-time PCR \\
\hline Konf1 & 382571 & $5^{\prime}$-GTAGAGACGGCTTGCATCGG-3' & 5'-TGTACGTTGGTCAGCTCCATC- $3^{\prime}$ & 185 & Real-time PCR \\
\hline Klf11 & 194655 & 5'-TGCACCTGATCTACCAAAGGAC-3' & 5'-AGTGGTTCCCTCTTGCTCAG-3' & 195 & Real-time PCR \\
\hline Lpin1 & 14245 & $5^{\prime}$-GAAAGGCCACAATACCGGAGA-3' & $5^{\prime}-$ TGTAGCTGACGTTGGACAAGAG-3' & 146 & Real-time PCR \\
\hline Nbas & 71169 & 5'-ATGCCTGTGATGTCTGCCTG-3' & 5'-TCATCTCTTCGCGTGCTTCTAC-3' & 129 & Real-time PCR \\
\hline Nol10 & 217431 & 5'-AGGGTTGGCGTGTTAGACTG-3' & 5'-CCCATACTGGTGATCCTTAACTAGC-3' & 189 & Real-time PCR \\
\hline Ntsr2 & 18217 & 5'-TGGCGGTTATCATGGGACAG-3' & $5^{\prime}-\mathrm{AAGGAGACCAGCACGTTCAC-3^{ \prime }}$ & 136 & Real-time PCR \\
\hline Odc1 & 18263 & $5^{\prime}$-CACATCGAGAACCATGAGCAG-3' & 5'-GTCCGCAACATAGAACGCATC-3' & 145 & Real-time PCR \\
\hline Pdia6 & 71853 & 5'-AGCCAAGAAGACATGCGAGG-3' & 5'-GAACCCTCCAATCCCTAGTGC-3' & 205 & Real-time PCR \\
\hline Pqlc3 & 217430 & 5'-TGTGGAAGGTACAAGATTCAGGAG-3' & $5^{\prime}$-CATTCAGCTTTGGTGGCAGAC- $3^{\prime}$ & 202 & Real-time PCR \\
\hline
\end{tabular}

ID, identification; Tv, transcript variant.

$\chi^{2}$ test $(P<0.01)$. To obtain B6N-based congenic mice carrying the $\mathrm{D} 2 \mathrm{Cr}$ mouse-derived $\mathrm{Chr} 12$, congenic mice were generated, as described previously, from crossing B6N and D2Cr mice $>10$ times. ${ }^{19}$ Congenic regions were examined by genotyping based on PCR for the microsatellite markers D12Mit182， D12Mit209，D12Mit169，D12Mit170, D12Mit58, D12Mit10, and D12Mit282.

\section{Deep Sequencing}

Kidneys from $\mathrm{B} 6 \mathrm{~N}$ and $\mathrm{D} 2 \mathrm{Cr}$ mice were collected, and genomic DNA was isolated using the DNeasy kit (Qiagen, Valencia, CA). Exome capture was performed using the Sureselect XT Mouse All Exon kit (Agilent Technologies, Santa Clara, CA). Whole-exome sequencing was performed with the HiSeq2000 system (Illumina, San Diego, CA). The University of California Santa Cruz (UCSC) Genome Browser [Dec.2011 (GRCm38/mm10)] (http://genome.ucsc. edu/cgi-bin/hgGateway, last accessed January 12, 2018) was used as the reference genome for alignment. The reads were mapped by BWA version 0.5.9 (http://bio-bwa. sourceforge.net). Single-nucleotide variants and small insertions/deletions were identified using SAMtools version 0.1.18 (http://samtools.sourceforge.net).

\section{Cell Culture}

M-1 kidney epithelial cells (Dainippon Sumitomo Pharma, Osaka, Japan) were maintained in Ham's F-12 mediumDulbecco's modified Eagle's medium (1:1) supplemented with $5 \%$ fetal bovine serum, $100 \mathrm{U} / \mathrm{mL}$ penicillin and streptomycin mixture, $2 \mathrm{mmol} / \mathrm{L}$ glutamine, and $5 \mu \mathrm{mol} / \mathrm{L}$ dexamethasone at $37^{\circ} \mathrm{C}$ in a humidified incubator with $5 \% \mathrm{CO}_{2}$. To obtain stable expression lines, M-1 cells were transfected with a Greb1 expression construct containing a cytomegalovirus promoter (Ex-Mm30281-M46; GeneCopoeia, Rockville, MD) using Xfect Transfection Reagent (Takara Bio USA, Inc., Mountain View, CA). Similarly, Ex-NEG-M46 (GeneCopoeia) was also transfected as a negative control. Stable transfectants were selected using G418 (1:100; Merck Millipore, Burlington, MA). The obtained cells were harvested on coverslips and stained with hematoxylin and eosin, and their morphology was analyzed by fluorescence microscopy using a BZ-X710 microscope equipped with a BZ-X analyzer (Keyence). Some cells were collected for gene expression analysis. 


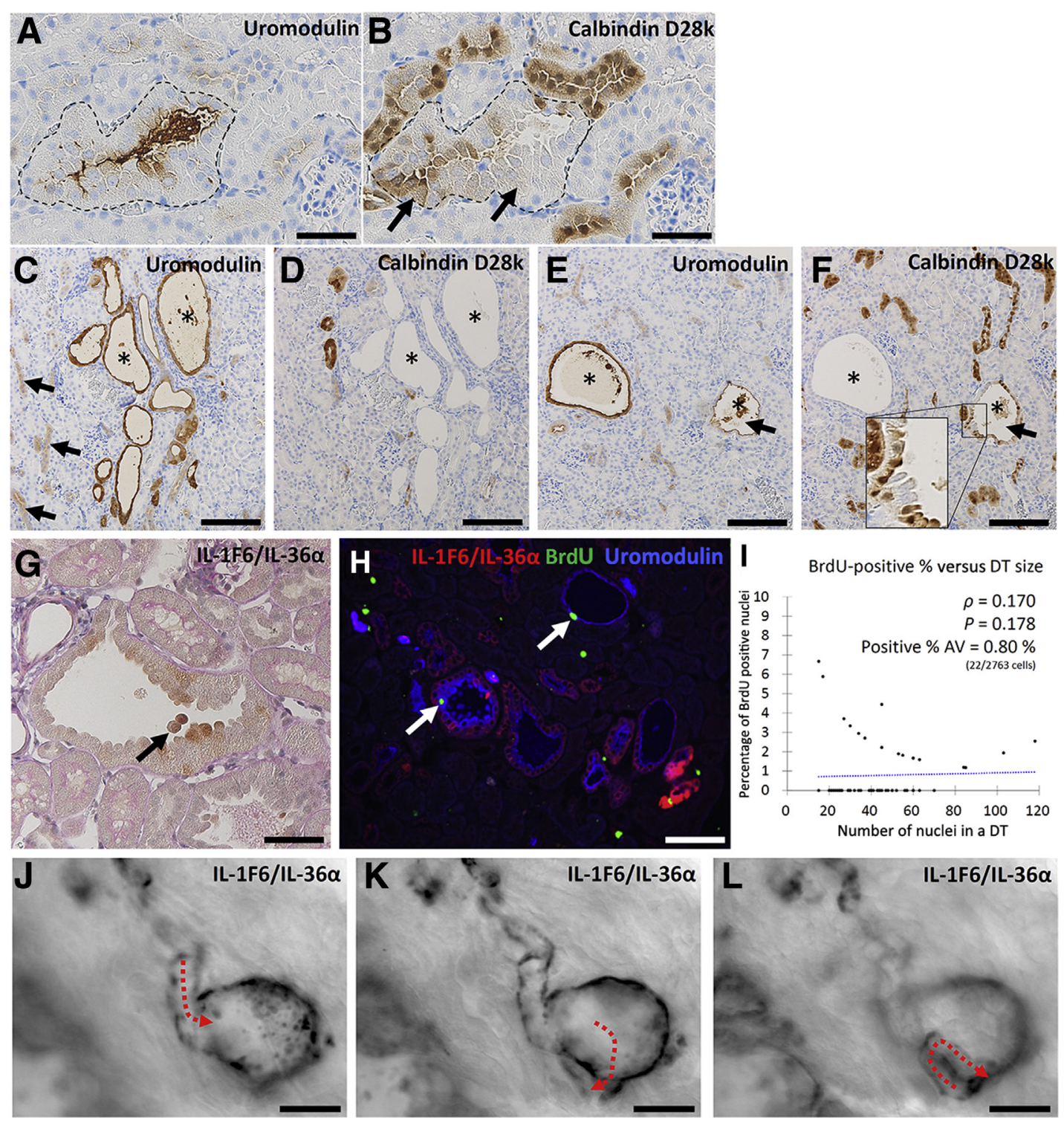

Figure 2 Morphologic characteristics of abnormal distal tubules (DTs) of DBA/2Cr (D2Cr) mice. A-F: Immunohistochemistry staining for uromodulin or calbindin D28k in kidneys of 8-month-old male D2Cr mice. A and B: Abnormal DTs (blue dotted line) in D2Cr mice express uromodulin and calbindin D28k having the apical localization (A) and the different staining intensity among DT epithelial cells (B, arrows), respectively. C and D: Many well-developed cysts were positive for uromodulin but not for calbindin D28k. Arrows in C indicate normal DTs positive for uromodulin. E and F: Dilated DTs positive for both uromodulin and calbindin D28k are also evident (arrows), and the cells lining these DTs were heterogeneously positive or negative for calbindin D28k ( $\mathbf{F}$, inset, shown at a threefold magnification) Asterisks in $\mathbf{C}-\mathbf{F}$ indicate the same DTs showing positive reactions for either uromodulin or calbindin D28k. G: Immunohistochemistry for IL-1 family member 6 (IL-1F6)/IL-36 $\alpha$ in kidneys of male 8-month-old D2Cr mice. Arrow indicates IL-1F6/IL-36 $\alpha-$ positive detached epithelial cells. H: Immunofluorescence for IL-1F6/IL-36 $\alpha$ (red), bromodeoxyuridine (BrdU; green), and uromodulin (blue) in kidneys of male 8month-old D2Cr mice. Arrows indicate BrdU containing DT epithelial cells. I: Correlation analysis between the percentage of BrdU-positive nuclei and the total number of nuclei in the DT of a D2Cr mouse. Dotted line indicates the approximate line. J-L: Whole-mount immunohistochemistry for IL-1F6/IL-36 $\alpha$ in kidneys of male 8-month-old D2Cr mice. Arrows indicate the entrance to ( $\mathbf{J})$ and exit from (K and L) abnormal IL-1F6/IL-36 $\alpha-$ positive DTs. Scale bars: $50 \mu \mathrm{m}$ (A, B, H, and $\mathbf{J}-\mathbf{L}) ; 100 \mu \mathrm{m}(\mathbf{C}-\mathbf{F}) ; 20 \mu \mathrm{m}(\mathbf{G})$.

\section{Gene Expression Analysis}

Total RNA isolated from kidneys and cultured cells was used as a template to synthesize cDNA using qPCR RT Master Mix with gDNA Remover (Toyobo, Osaka, Japan). PCR was performed using Grebl-specific primers and cDNA templates, and the amplified samples were used for $2 \%$ agarose gel electrophoresis and imaging under LED illumination. Quantitative PCR analysis was performed using Brilliant III SYBR Master Mix for kidneys (Agilent Technologies) and specific primers (Table 2) with an MX3000P system (Agilent Technologies). The specificity of each PCR was confirmed by melting curve analysis. The expression data were normalized to the expression levels of the genes for $\beta$-actin $(A c t b)$ or glyceraldehyde-3-phosphate dehydrogenase (Gapdh). 

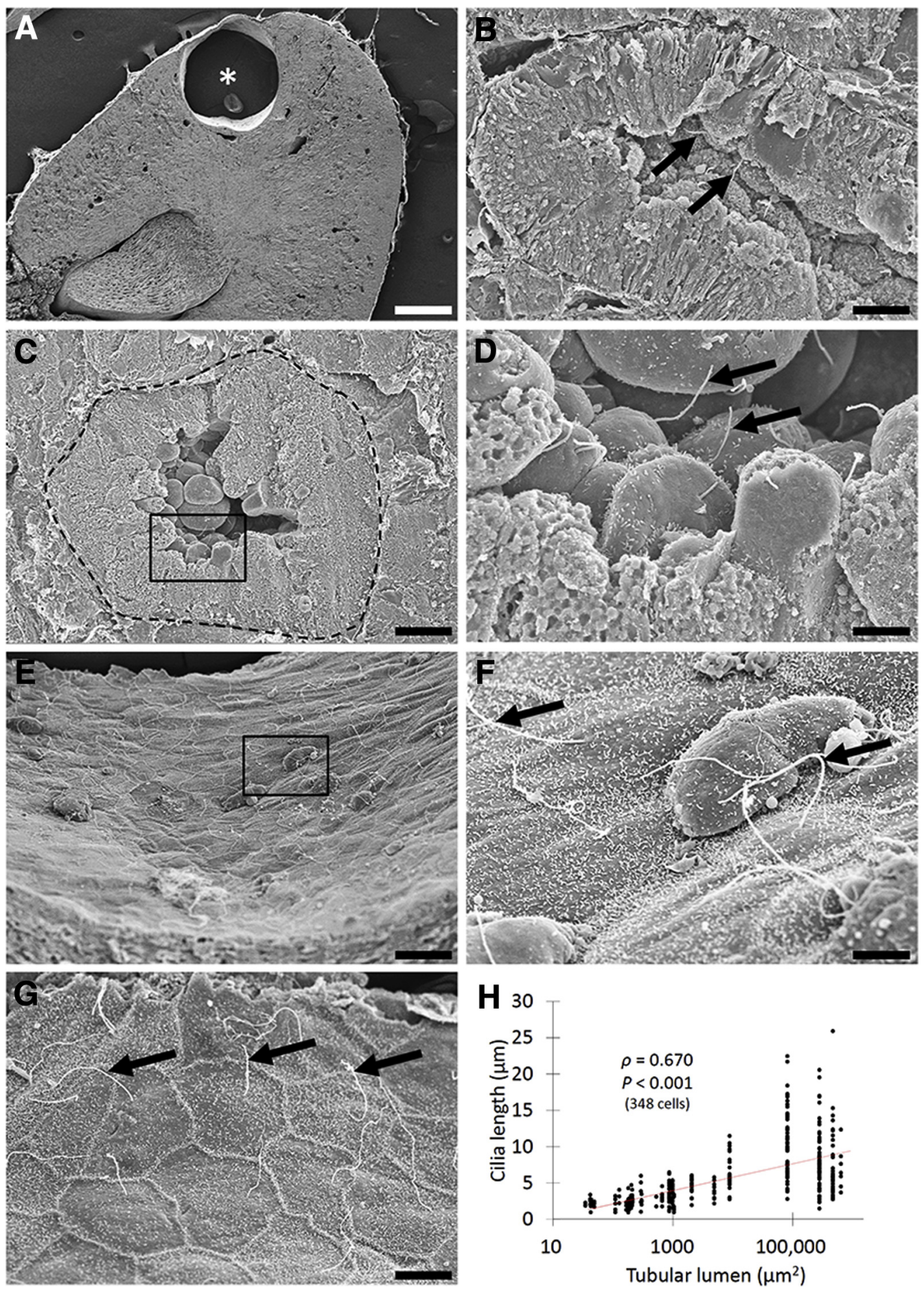

Figure 3 Scanning electron microscopy (SEM) examination of ultrastructure of abnormal distal tubule (DT) of DBA/2Cr (D2Cr) mice. A-G: SEM images of kidney sections from female 8-month-old D2Cr mice. A: The asterisk indicates a large cyst. B: The normal DT morphology with primary cilia (arrows). C: Abnormal DTs (dotted line) have columnar epithelial cells. D: A higher magnification view of the boxed area marked in C. The apical surface of DT epithelial cells has a dome shape with primary cilia (arrows). E-G: Surfaces of cystic DTs are covered with flattened, polygonal, epithelial cells (E-G) with elongated primary cilia (F and $\mathbf{G}$, arrows). F: A higher-magnification view of the boxed area marked in $\mathbf{E}$. H: Correlation analysis between the cilia length and tubular lumen in a DT from a D2Cr mouse. Dotted line indicates the approximate line. Scale bars: $500 \mu \mathrm{m}(\mathbf{A}) ; 5 \mu \mathrm{m}(\mathbf{B}$ and $\mathbf{G}) ; 25 \mu \mathrm{m}(\mathbf{C}$ and $\mathbf{E}) ; 6 \mu \mathrm{m}(\mathbf{D}$ and $\mathbf{F})$.

\section{Statistical Analysis}

All statistical analyses were performed in a nonparametric manner. $U$-test $(P<0.05)$ was used for comparisons between two groups. For multiple comparisons, Dunnett's test $(P<0.05)$ was performed when statistical significance was observed with the Kruskal-Wallis test $(P<0.05)$. 
Distal Tubule Abnormality in Inbred Mice
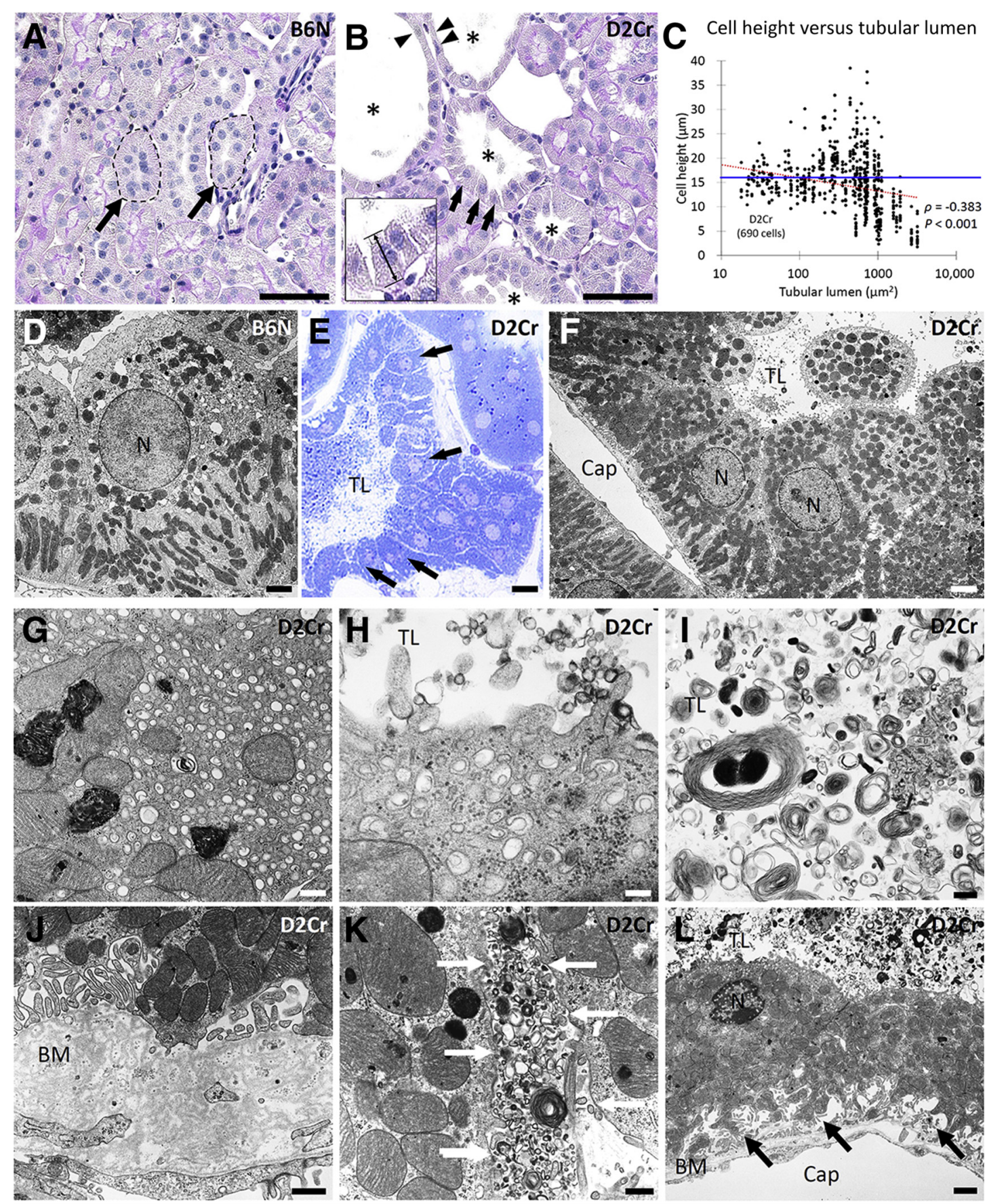

Figure 4 Light microscopy and transmission electron microscopy (TEM) examinations of ultrastructure of abnormal distal tubule (DT) epithelial cells in $\mathrm{DBA} / 2 \mathrm{Cr}(\mathrm{D} 2 \mathrm{Cr}$ ) mice. A and B: Periodic acid-Schiff-stained kidney sections. C57BL/6N (B6N) mouse showing normal DT epithelial cells characterized by undeveloped brush border and apical localizations of nuclei (A, dotted lines and arrows). However, abnormal DTs (asterisks) in a D2Cr mouse show greater cell heights and wider intercellular spaces. These characteristics are prominent in the DTs having columnar epithelial cells (arrows), rather than more dilated tubules (arrowheads). Inset: The measurement of cell height in graph in C. C: Scatter plot of the cell heights ( $y$ axis) and tubular lumen ( $x$ axis) in a DT from a D2Cr mouse. The blue line indicates the average of cell heights $(12.2 \mu \mathrm{m}, 216$ cells) examined in B6N mice. Red dotted line indicates the approximate line in D2Cr. D: Kidney sections of a male 8-month-old B6N mouse examined using TEM. DT epithelial cells show normal features with well-developed basal infoldings and regular mitochondria. E: Semithin toluidine blue-stained kidney sections of a male 8-month-old D2Cr mouse. This panel shows a highmagnification image of abnormal DT epithelial cells showing a columnar shape and increased intercellular space (arrows). F-L: Kidney sections of a male 8-month-old D2Cr mouse examined using TEM. F: Abnormal DT epithelial cells show increased intercellular space and abundant irregularly arranged mitochondria. $\mathbf{G}$ and $\mathbf{H}$ : The cytoplasm of abnormal DT epithelial cells contains numerous horseshoe-like vesicles (G), which are also abundant in the apical portion of abnormal DT cytoplasm (H). I: Lamellar-like structures are abundantly observed in the lumens of abnormal DT. J: In abnormal DT, the basal membrane (BM) is thickened and basal infolding is irregular. K: In the increased intercellular space, numerous lamellar-like structures are observed (arrows). L: Epithelial detachment is also observed in abnormal DT (arrows). Scale bars: $50 \mu \mathrm{m}(\mathbf{A}$ and B); $1 \mu \mathrm{m}$ (D and L); $10 \mu \mathrm{m}(\mathbf{E}) ; 2 \mu \mathrm{m}(\mathbf{F}) ; 200 \mathrm{~nm}(\mathbf{G}$ and I-K); 100 nm (H). Cap, capillary; N, nucleus; TL, tubular lumen. 



Figure 5 Molecular expression associated with morphofunction of distal tubules (DTs) in kidney of DBA/2Cr (D2Cr) mice. A: Expression of genes associated with the intracellular vesicle function in the kidney of mice at 6 months of age, as determined by real-time PCR. A significant difference between C57BL/6N (B6N) mice and D2Cr mice is indicated. B and C: Immunohistochemistry for CD9 in kidneys of 6-month-old D2Cr mice. Positive reactions are detected at the basal portion of DTs, but not in abnormal DTs (asterisks). C: A higher magnification view of the boxed area in B. Epithelial cells of abnormal DTs are negative for CD9 (arrows). D: Gene expression associating with the intercellular adhesion in the kidney at 6 months of age. Real-time PCR. A significant difference between $\mathrm{B} 6 \mathrm{~N}$ mice and D2Cr mice is indicated. E-G: Immunohistochemistry for E-cadherin, $\mathrm{CD} 9$, and $\mathrm{Na}^{+} / \mathrm{K}^{+}$ATPase in kidneys of 6 -month-old D2Cr mice. These positive reactions are strong at the basal portion of DTs, but are more clearly localized to the lateral membrane of epithelial cells in abnormal DTs (asterisks, insets, and arrows). G: The positive reaction of $\mathrm{Na}^{+} / \mathrm{K}^{+}$ATPase was lacking in some epithelial cells of abnormal DTs (arrowheads). Insets in $\mathbf{E}-\mathbf{G}$ show threefold magnification views of the boxed areas. $\mathrm{H}$ : Correlation analysis between the $\mathrm{Na}^{+} / \mathrm{K}^{+}$ATPase intensity ratio (lateral/basal) and tubular lumen in a DT of a D2Cr mouse. Red dotted line indicates the approximate line. Values are expressed as means $\pm \mathrm{SEM}(\mathbf{A}$ and $\mathbf{D}) . n=8$ kidneys $(\mathbf{A}$ and $\mathbf{D}) .{ }^{*} P<0.05$, ${ }^{* *} P<0.01$. Scale bars: $100 \mu \mathrm{m}(\mathbf{B}) ; 50 \mu \mathrm{m}(\mathbf{E}-\mathbf{G})$.

Spearman's correlation test $(P<0.05)$ was used to analyze the correlation between two parameters.

\section{Results}

\section{Abnormal DTs Found in the Inbred Mouse Strains}

First, the renal histology among inbred mouse strains was compared (Figure 1). Normal DT epithelium was observed in B6N mice (Figure 1A). However, in D2Cr mice, columnar epithelial cells and dilated lumens were observed (Figure 1, B and C). In the D2Cr mice, these seemed to be DT segments because they showed several morphologic characteristics of DT, such as undeveloped brush border compared with PT, with some being attached with renal corpuscles as macula densa (Figure 1B). Some D2Cr mice, especially older mice, showed cystic tubules (Figure 1D). Older D2Cr mice tended to have more and larger cysts
(Figure 1E). Developed cysts occupied the renal cortex of some D2Cr mice (Figure 1F). Similar renal tubule abnormalities were observed in the $\mathrm{A} / \mathrm{J}, \mathrm{C} 3 \mathrm{H} / \mathrm{He}, \mathrm{DBA} / 1 \mathrm{~J}$, and $\mathrm{FVB} / \mathrm{N}$ mice, and these tubules showed the immunepositive reactions for uromodulin and calbindin D28k, epithelial cell markers for straight and convoluted segments of DTs, respectively (Figure 1, G and $\mathrm{H}$ ). In a comparison of DT abnormality scores at 5 to 8 months of age, both sexes of $\mathrm{D} 2 \mathrm{Cr}$ mice showed high scores among the strains examined (Figure 1I). The DT abnormality scores of D2Cr male mice were significantly higher than those of $\mathrm{C} 3 \mathrm{H} / \mathrm{He}$, DBA/1J, and FVB/N males (Figure 1I). D2Cr mice showed no significant differences in DT abnormality scores between males and females, but female $\mathrm{C} 3 \mathrm{H} / \mathrm{He}$ mice showed higher scores than $\mathrm{C} 3 \mathrm{H} / \mathrm{He}$ males. DT abnormality scores of both sexes of D2Cr mice tended to increase with age, and a significant increase was observed at 24 to 32 weeks of age compared with 10 weeks in both sexes (Figure $1 \mathrm{~J}$ ). 
Table 3 Appearance of Distal Tubular Lesions in D2Cr and Their Progeny with B6N

\begin{tabular}{|c|c|c|c|c|c|c|c|}
\hline \multirow[b]{2}{*}{ Strain } & \multirow[b]{2}{*}{ Sex } & \multirow[b]{2}{*}{ Age, weeks } & \multicolumn{5}{|l|}{ Grade* } \\
\hline & & & 1 & 2 & 3 & 4 & 5 \\
\hline \multirow[t]{3}{*}{$\mathrm{D} 2 \mathrm{Cr}$} & Male & 10 & $33(6 / 18)$ & $17(3 / 18)$ & $17(3 / 18)$ & $11(2 / 18)$ & $0(0 / 18)$ \\
\hline & & $12-14$ & $38(5 / 13)$ & $38(5 / 13)$ & $38(5 / 13)$ & $23(4 / 13)$ & $0(0 / 13)$ \\
\hline & & $24-32$ & $56(5 / 9)$ & $67(6 / 9)$ & $67(6 / 9)$ & $44(4 / 9)$ & $22(2 / 9)$ \\
\hline \multirow[t]{3}{*}{$\mathrm{D} 2 \mathrm{Cr}$} & Female & 10 & $0(0 / 7)$ & $0(0 / 7)$ & $0(0 / 7)$ & $0(0 / 7)$ & $0(0 / 7)$ \\
\hline & & $12-14$ & $50(2 / 4)$ & $50(2 / 4)$ & $25(1 / 4)$ & $25(1 / 4)$ & $0(0 / 4)$ \\
\hline & & $24-32$ & $33(3 / 9)$ & $56(5 / 9)$ & $33(3 / 9)$ & $22(2 / 9)$ & $0(0 / 9)$ \\
\hline \multirow[t]{4}{*}{$\mathrm{DBF}_{1}^{\dagger}$} & Male & 10 & $0(0 / 4)$ & $0(0 / 4)$ & $0(0 / 4)$ & $0(0 / 4)$ & $0(0 / 4)$ \\
\hline & & $28-32$ & $0(0 / 6)$ & $0(0 / 6)$ & $0(0 / 6)$ & $0(0 / 6)$ & $0(0 / 6)$ \\
\hline & Female & 10 & $0(0 / 6)$ & $0(0 / 6)$ & $0(0 / 6)$ & $0(0 / 6)$ & $0(0 / 6)$ \\
\hline & & $28-32$ & $0(0 / 3)$ & $0(0 / 3)$ & $0(0 / 3)$ & $0(0 / 3)$ & $0(0 / 3)$ \\
\hline \multirow[t]{4}{*}{$\mathrm{BDF}_{1}^{\dagger}$} & Male & 10 & $0(0 / 10)$ & $0(0 / 10)$ & $0(0 / 10)$ & $0(0 / 10)$ & $0(0 / 10)$ \\
\hline & & $28-32$ & $0(0 / 5)$ & $0(0 / 5)$ & $0(0 / 5)$ & $0(0 / 5)$ & $0(0 / 5)$ \\
\hline & Female & 10 & $0(0 / 5)$ & $0(0 / 5)$ & $0(0 / 5)$ & $0(0 / 5)$ & $0(0 / 5)$ \\
\hline & & $28-32$ & $0(0 / 10)$ & $0(0 / 10)$ & $0(0 / 10)$ & $0(0 / 10)$ & $0(0 / 10)$ \\
\hline \multirow[t]{2}{*}{$\mathrm{N} 2^{\S}$} & Male & 12 & $11(5 / 45)$ & $16(7 / 45)$ & $9(4 / 45)$ & $4(2 / 45)$ & $0(0 / 45)$ \\
\hline & Female & 12 & $12(6 / 51)$ & $12(6 / 51)$ & $12(6 / 51)$ & $6(3 / 51)$ & $2(1 / 51)$ \\
\hline \multirow[t]{2}{*}{$\mathrm{F}_{2}^{\S}$} & Male & 10 & $6(5 / 84)$ & $6(5 / 84)$ & $6(5 / 84)$ & $0(0 / 84)$ & $0(0 / 84)$ \\
\hline & & 24 & $6(9 / 153)$ & $5(7 / 153)$ & $5(8 / 153)$ & $5(7 / 153)$ & $2(3 / 153)$ \\
\hline
\end{tabular}

Number $=$ animals.

*Data are given as percentage (number/total).

${ }^{\dagger}$ Female $\mathrm{D} 2 \mathrm{Cr} \times$ male $\mathrm{B} 6 \mathrm{~N}$.

${ }^{\ddagger}$ Female $\mathrm{B} 6 \mathrm{~N} \times$ male $\mathrm{D} 2 \mathrm{Cr}$.

${ }^{\S}$ Female $\mathrm{DBF}_{1} \times$ male $\mathrm{DBF}_{1}$, female $\mathrm{BDF}_{1} \times$ male $\mathrm{BDF}_{1}$, and female $\mathrm{BDF}_{1} \times$ male $\mathrm{D} 2 \mathrm{Cr}$.

$\mathrm{B} 6 \mathrm{~N}, \mathrm{C} 57 \mathrm{BL} / 6 \mathrm{~N} ; \mathrm{BDF}_{1},(\mathrm{~B} 6 \mathrm{~N} \times \mathrm{D} 2 \mathrm{Cr}) ; \mathrm{D} 2 \mathrm{Cr}, \mathrm{DBA} / 2 \mathrm{Cr} ; \mathrm{DBF}_{1},(\mathrm{D} 2 \mathrm{Cr} \times \mathrm{B} 6 \mathrm{~N}) \mathrm{F}_{1} ; \mathrm{F}_{2}, \mathrm{BDF}_{1} \times \mathrm{BDF}_{1} ; \mathrm{N} 2, \mathrm{BDF}_{1} \times \mathrm{D}_{2} \mathrm{Cr}$.

\section{Characteristics of Abnormal DTs in D2Cr Mice}

Because the D2Cr mice more obviously displayed DT abnormalities without sex-related differences compared with the other strains that were examined (Figure 1), the $\mathrm{D} 2 \mathrm{Cr}$ mice were investigated more intensively. Immunohistochemistry analysis of abnormal tubules from D2Cr mice revealed the expression of uromodulin and calbindin D28k, which displayed apical localization and different staining intensities among DT epithelial cells, respectively (Figure 2, A and B). Many well-developed cysts were positive for uromodulin but not for calbindin D28k (Figure 2, C and D). In addition, large cysts that were positive for both uromodulin and calbindin D28k were observed, and those lining the epithelium showed heterogeneous cell patterns, with some being positive for calbindin D28k and others being negative, similar with Figure 2B (Figure 2, E and F). Detached epithelial cells in dilated DTs were also positive for the DT injury marker IL-1F6/IL-36 $\alpha^{20}$ (Figure 2, G and H). Some dilated DTs of D2Cr mice also incorporated BrdU (Figure 2H). However, the percentage of cells with BrdU in their nuclei did not increase with the development of DT abnormalities (Figure 2I). Whole-mount immunohistochemistry for IL-1F6/IL-36 $\alpha$ revealed continuous connections between nondilated tubule portions and cystic structures in the DTs of D2Cr mice (Figure 2, $\mathrm{J}-\mathrm{L}$ ).

\section{Characteristics of Abnormal DT Epithelial Cells in D2Cr Mice}

Next, abnormal DT epithelial cells were examined in D2Cr mice using scanning electron microscopy and transmission electron microscopy (Figure 3). Occasionally, large cysts were noted in the renal cortex of D2Cr mice (Figure 3A). Compared with DT segments having a normal morphology (Figure 3B), the affected DT epithelial cells in $\mathrm{D} 2 \mathrm{Cr}$ mice showed an increased major axis with a columnar and apical dome shape, elongated primary cilia, and apical spherical structures (Figure 3, C and D). The surfaces of larger cystic tubules were covered by polygonal squamous epithelial cells with microvilli and elongated primary cilia (Figure 3, E-G). In D2Cr mice, the primary cilia varied markedly in length in the abnormal DTs, and a significant positive correlation was observed between cilia length and tubular lumen area (Figure $3 \mathrm{H}$ ). The heights and the intercellular spaces of epithelial cells composed of abnormal DT in D2Cr mice were higher and wider compared with those of DT epithelial cells in B6N mice (Figure 4, A and B). More important, some abnormal epithelial cells showed higher heights with the dilated tubular lumen (Figure 4C), but they were significantly decreased with the development of cysts, indicating a squamous morphology. Transmission electron microscopy observation of B6N DT epithelial cells revealed normal structures characterized by basal 
infolding with regular arrangement of mitochondria (Figure 4D). However, in semistained sections, abnormal DT epithelial cells displayed increased intracellular space (Figure 4, E and F) and the number of mitochondria also tended to be increased in some abnormal DTs of D2Cr mice (Figure 4F). Moreover, cytoplasmic horseshoe-like vesicles were abundantly observed (Figure 4G). These vesicles were also observed in the apical portion of the cytoplasm, and vesicles or lamellar-like structures were also found in the lumen of abnormal DTs (Figure 4, $\mathrm{H}$ and I). Furthermore, irregular basal infolding, thickened basal membrane, and increased intercellular space with loose intercellular adhesions and numerous vesicles were observed in the abnormal DTs in D2Cr mice (Figure 4, $\mathrm{J}-\mathrm{L}$ ).

\section{Molecular Expression Patterns of DTs in D2Cr Mice}

On the basis of the results of the morphologic observations, it was predicted that genes associated with DT morphofunction would show altered transcript and/or protein expression patterns in DTs of D2Cr mice. Expression of $C d 9$, an extracellular vesicle marker and an important osmotic stress-related molecule in DTs, ${ }^{21}$ was significantly decreased in $\mathrm{D} 2 \mathrm{Cr}$ mice compared with $\mathrm{B} 6 \mathrm{~N}$ mice (Figure 5A). However, expression of another extracellular vesicle marker, tumor susceptibility gene 101 (Tsg101), and autophagy-related 8a (Atg8a), Atg8b, and Atg12 did not differ between $\mathrm{D} 2 \mathrm{Cr}$ and $\mathrm{B} 6 \mathrm{~N}$ mice.

Interestingly, the immunohistochemical analysis indicated that CD9 was basally localized in normal DT epithelium (Figure 5B), whereas CD9 expression was faint in abnormal DTs in D2Cr mice (Figure 5, B and C). Gene expression of cell adhesion molecules, including Ecadherin/cadherin 1 (Cdhl), tight junction protein-1 (Tjp1)/zonula occludens-1, and occludin (Ocln), was significantly lower in the renal tissue of $\mathrm{D} 2 \mathrm{Cr}$ mice than in kidney tissue of B6N mice (Figure 5D). E-cadherin protein was basally localized in normal DT epithelium, but showed strong lateral localization in abnormal DTs (Figure 5E). Furthermore, although there was no difference in claudin 3 ( Cldn3) gene expression between $\mathrm{D} 2 \mathrm{Cr}$ and B6N kidneys, claudin 3 protein expression was stronger in the lateral portions of abnormal DT epithelial cells than in normal ones in $\mathrm{D} 2 \mathrm{Cr}$ mice (Figure $5 \mathrm{~F}$ ). Finally, $\mathrm{Na}^{+} / \mathrm{K}^{+}$ATPase, an important molecule for the development of cystic lesions, ${ }^{22}$ was basally localized in renal tubules, but showed strong localization to the lateral membranes of abnormal DT epithelial cells (Figure 5G). To identify representative molecules to examine these basal to lateral translocations, the ratio of $\mathrm{Na}^{+} / \mathrm{K}^{+}$ ATPase-positive intensity was also calculated in the lateral side to that in the basal side in DT epithelial cells of $\mathrm{D} 2 \mathrm{Cr}$ mice (Figure 5H). A severe variance was observed among cells, and epithelial cells having a higher ratio of $\mathrm{Na}^{+} / \mathrm{K}^{+}$ATPase-positive intensity was significantly increased with the dilation of DTs. Thus, these data indicate that molecules associated with DT morphofunction showed altered patterns of gene expression and/or protein localization in D2Cr abnormal DTs.

\section{Genetic Factors Regulating the Appearance of Abnormal DTs in D2Cr Mice}

Table 3 summarizes the rate of each histopathological grade of abnormal DTs in D2Cr mice and their progeny obtained from mating with $\mathrm{B} 6 \mathrm{~N}$ mice. No abnormal DTs were observed in the $\mathrm{F}_{1}$ progeny [(D2Cr $\left.\times \mathrm{B} 6 \mathrm{~N}\right) \mathrm{F}_{1}$ and $\mathrm{BDF}_{1}$ ]. This indicated that the trait was regulated in a recessive manner in $\mathrm{D} 2 \mathrm{Cr}$ mice and that the $\mathrm{Y}$ chromosome was not responsible. However, abnormal DTs appeared in some N2 and $F_{2}$ progeny, indicating either an autosomal or an $\mathrm{X}$-chromosomal contribution. Linkage analysis was performed with $\mathrm{N} 2$ or $\mathrm{F}_{2}$ progeny that showed DT abnormalities (Table 4). One significant linkage was found on the telomeric region of the D2Cr-type Chr 12, and the $\mathrm{F}_{2}$ and N2 progeny displayed statistical significance for the D12Mit182-D12Mit5 (5.52 to $37.16 \mathrm{cM}$ ) and D12Mit182D12Mit83 (5.52 to $9.69 \mathrm{cM})$ intervals, respectively $(P<0.01)$. From the $\mathrm{N} 2$ analysis, this candidate locus on mouse Chr 12 (D12Mit182-D12Mit83) was defined as $\mathrm{DBA} / 2$ renal cyst (drecy).

Further examination of $\mathrm{N} 2$ and $\mathrm{F}_{2}$ progeny mice with DT abnormalities revealed two individuals carrying the necessary genotypes to narrow the candidate region in drecy (Figure 6A). Twenty-five candidate protein-coding genes on D12Mit169-D12Mit282 were studied (Figure 6B). At 4 weeks, renal gene expression levels of Greb1, nucleolar protein 10 (Nol10), PQ loop repeat containing (Pqlc3), tribbles pseudokinase 2 (Trib2), Rhoassociated coiled-coil containing protein kinase 2 (Rock2), ornithine decarboxylase, structural $1(\operatorname{Odcl})$, and lipin 1 (Lpin1) differed between D2Cr and B6N mice. At 8 weeks, renal gene expression levels of Greb1, grainyhead-like transcription factor 1 (Grhll), potassium voltage-gated channel, subfamily $\mathrm{F}$, member 1 (Kcnfl), and Lpin1 differed between D2Cr and B6N mice (Figure 6B). Most notably, renal Grebl expression was significantly higher in D2Cr mice than in $\mathrm{B} 6 \mathrm{~N}$ mice at both 4 and 8 weeks (5.26and 11.80-fold, respectively). Therefore, Grebl was studied further.

Mouse Grebl has two transcript variants (Tvs). The expression of both Grebl Tvs (Tv1 and Tv2) was examined in several mouse organs by RT-PCR (Figure 6C). A Tv1 band alone was not detected in the kidney, but the primers amplifying both Tv1 and Tv2 showed a specific band in kidney tissue. The band was more evident in samples from $\mathrm{D} 2 \mathrm{Cr}$ mice than in samples from B6N mice. Exome sequencing identified five singlenucleotide polymorphisms associated with an amino acid substitution between the genomes of $\mathrm{B} 6 \mathrm{~N}$ and $\mathrm{D} 2 \mathrm{Cr}$ mice (Table 5). 
Distal Tubule Abnormality in Inbred Mice

Table 4 Summary of Genetic Linkage Analysis for the Appearance of Abnormal DT in D2Cr

\begin{tabular}{|c|c|c|c|c|c|c|c|c|c|c|}
\hline \multirow[b]{2}{*}{ Chr } & \multirow[b]{2}{*}{ Marker } & \multirow[b]{2}{*}{$\mathrm{CM}$} & \multicolumn{3}{|c|}{ Genotype $\left(F_{2}\right)$} & \multicolumn{3}{|c|}{ Genotype (N2) } & \multirow[b]{2}{*}{$\chi^{2}$ Test $\left(\mathrm{F}_{2}\right)$} & \multirow[b]{2}{*}{$\chi^{2}$ Test (N2) } \\
\hline & & & $B B$ & $B D$ & $D D$ & $B B$ & $B D$ & $D D$ & & \\
\hline \multirow[t]{3}{*}{1} & 211 & 10.59 & $3 / 10$ & $4 / 10$ & $3 / 10$ & $0 / 13$ & $6 / 13$ & $7 / 13$ & 0.837 & 0.958 \\
\hline & 103 & 59.48 & $2 / 10$ & $4 / 10$ & $3 / 10$ & $0 / 13$ & $6 / 13$ & $7 / 13$ & 0.934 & 0.958 \\
\hline & 541 & 81.02 & $3 / 10$ & $3 / 10$ & $4 / 10$ & $0 / 13$ & $7 / 13$ & $6 / 13$ & 0.748 & 0.542 \\
\hline \multirow[t]{2}{*}{2} & 369 & 24.51 & $5 / 10$ & $2 / 10$ & $3 / 10$ & $0 / 13$ & $7 / 13$ & $6 / 13$ & 0.104 & 0.542 \\
\hline & 229 & 88.99 & $4 / 10$ & $2 / 10$ & $4 / 10$ & $0 / 13$ & $7 / 13$ & $6 / 13$ & 0.291 & 0.542 \\
\hline \multirow[t]{4}{*}{3} & 164 & 2.00 & $2 / 10$ & $6 / 10$ & $2 / 10$ & $0 / 13$ & $6 / 13$ & $7 / 13$ & 0.440 & 0.958 \\
\hline & 182 & 21.70 & $2 / 10$ & $5 / 10$ & $3 / 10$ & $0 / 13$ & $6 / 13$ & $7 / 13$ & 0.846 & 0.958 \\
\hline & 12 & 43.70 & $2 / 10$ & $5 / 10$ & $3 / 10$ & $0 / 13$ & $7 / 13$ & $6 / 13$ & 0.846 & 0.542 \\
\hline & 346 & 50.20 & $2 / 10$ & $5 / 10$ & $3 / 10$ & $0 / 13$ & $7 / 13$ & $6 / 13$ & 0.846 & 0.542 \\
\hline \multirow{3}{*}{4} & 248 & 52.31 & $4 / 10$ & $2 / 10$ & $4 / 10$ & $0 / 13$ & $6 / 13$ & $7 / 13$ & 0.291 & 0.958 \\
\hline & 12 & 57.60 & $3 / 10$ & $4 / 10$ & $3 / 10$ & $0 / 13$ & $4 / 13$ & $9 / 13$ & 0.837 & 0.289 \\
\hline & 127 & 80.52 & $2 / 10$ & $3 / 10$ & $5 / 10$ & $0 / 13$ & $3 / 13$ & $10 / 13$ & 0.655 & 0.106 \\
\hline \multirow[t]{5}{*}{5} & 346 & 2.62 & $3 / 10$ & $5 / 10$ & $2 / 10$ & $0 / 13$ & $6 / 13$ & $7 / 13$ & 0.556 & 0.958 \\
\hline & 108 & 23.91 & $4 / 10$ & $3 / 10$ & $3 / 10$ & $0 / 13$ & $6 / 13$ & $7 / 13$ & 0.416 & 0.958 \\
\hline & 197 & 32.92 & $3 / 10$ & $3 / 10$ & $4 / 10$ & $0 / 13$ & $5 / 13$ & $8 / 13$ & 0.748 & 0.614 \\
\hline & 20 & 47.77 & $3 / 10$ & $3 / 10$ & $4 / 10$ & $0 / 13$ & $4 / 13$ & $9 / 13$ & 0.748 & 0.289 \\
\hline & 168 & 76.15 & $1 / 10$ & $5 / 10$ & $4 / 10$ & $0 / 13$ & $5 / 13$ & $8 / 13$ & 0.626 & 0.614 \\
\hline \multirow[t]{3}{*}{6} & 159 & 12.36 & $1 / 10$ & $3 / 10$ & $6 / 10$ & $0 / 13$ & $6 / 13$ & $7 / 13$ & 0.279 & 0.958 \\
\hline & 74 & 23.70 & $1 / 10$ & $4 / 10$ & $5 / 10$ & $0 / 13$ & $7 / 13$ & $6 / 13$ & 0.542 & 0.542 \\
\hline & 10 & 52.75 & $2 / 10$ & $2 / 10$ & $6 / 10$ & $0 / 13$ & $4 / 13$ & $9 / 13$ & 0.264 & 0.289 \\
\hline \multirow{2}{*}{8} & 211 & 52.00 & $3 / 10$ & $4 / 10$ & $3 / 10$ & $0 / 13$ & $8 / 13$ & $5 / 13$ & 0.837 & 0.243 \\
\hline & 200 & 61.37 & $3 / 10$ & $3 / 10$ & $4 / 10$ & $0 / 13$ & $8 / 13$ & $5 / 13$ & 0.748 & 0.243 \\
\hline 9 & 90 & 17.80 & $2 / 10$ & $7 / 10$ & $1 / 10$ & $0 / 13$ & $7 / 13$ & $6 / 13$ & 0.136 & 0.542 \\
\hline & 289 & 38.58 & $1 / 10$ & $7 / 10$ & $2 / 10$ & $0 / 13$ & $7 / 13$ & $6 / 13$ & 0.175 & 0.542 \\
\hline & 35 & 51.41 & $3 / 10$ & $4 / 10$ & $4 / 10$ & $0 / 13$ & $8 / 13$ & $5 / 13$ & 0.865 & 0.243 \\
\hline & 51 & 57.46 & $3 / 10$ & $5 / 10$ & $2 / 10$ & $0 / 13$ & $8 / 13$ & $5 / 13$ & 0.556 & 0.243 \\
\hline & 18 & 71.49 & $2 / 10$ & $4 / 10$ & $4 / 10$ & $0 / 13$ & $9 / 13$ & $4 / 13$ & 0.966 & 0.085 \\
\hline 10 & 248 & 5.21 & $2 / 10$ & $5 / 10$ & $3 / 10$ & $0 / 13$ & $5 / 13$ & $8 / 13$ & 0.846 & 0.614 \\
\hline & 213 & 9.75 & $2 / 10$ & $5 / 10$ & $3 / 10$ & $0 / 13$ & $5 / 13$ & $8 / 13$ & 0.846 & 0.614 \\
\hline & 3 & 16.53 & $2 / 10$ & $6 / 10$ & $2 / 10$ & $0 / 13$ & $7 / 13$ & $6 / 13$ & 0.440 & 0.542 \\
\hline & 61 & 34.80 & $2 / 10$ & $4 / 10$ & $4 / 10$ & $0 / 13$ & $5 / 13$ & $8 / 13$ & 0.966 & 0.614 \\
\hline & 186 & 38.56 & $2 / 10$ & $4 / 10$ & $4 / 10$ & $0 / 13$ & $6 / 13$ & $7 / 13$ & 0.966 & 0.958 \\
\hline & 230 & 45.28 & $1 / 10$ & $7 / 10$ & $2 / 10$ & $0 / 13$ & $6 / 13$ & $7 / 13$ & 0.175 & 0.958 \\
\hline & 134 & 54.72 & $1 / 10$ & $7 / 10$ & $2 / 10$ & $0 / 13$ & $7 / 13$ & $6 / 13$ & 0.175 & 0.542 \\
\hline 11 & 226 & 5.64 & $2 / 10$ & $6 / 10$ & $2 / 10$ & $0 / 13$ & $5 / 13$ & $8 / 13$ & 0.440 & 0.614 \\
\hline & 21 & 25.94 & $1 / 10$ & $7 / 10$ & $2 / 10$ & $0 / 13$ & $6 / 13$ & $7 / 13$ & 0.175 & 0.958 \\
\hline & 212 & 54.34 & $3 / 10$ & $6 / 10$ & $1 / 10$ & $0 / 13$ & $6 / 13$ & $7 / 13$ & 0.220 & 0.958 \\
\hline & 48 & 82.96 & $3 / 10$ & $6 / 10$ & $1 / 10$ & $0 / 13$ & $9 / 13$ & $4 / 13$ & 0.220 & 0.085 \\
\hline 12 & 182 & 5.52 & $0 / 10$ & $0 / 10$ & $10 / 10$ & $0 / 13$ & $0 / 13$ & $13 / 13$ & $<0.001^{\dagger}$ & $0.001^{\dagger}$ \\
\hline & 169 & 7.03 & $0 / 10$ & $0 / 10$ & $10 / 10$ & $0 / 13$ & $0 / 13$ & $13 / 13$ & $<0.001^{\dagger}$ & $0.001^{\dagger}$ \\
\hline & 12 & 8.49 & $0 / 10$ & $0 / 10$ & $10 / 10$ & $0 / 13$ & $1 / 13$ & $12 / 13$ & $<0.001^{\dagger}$ & $0.006^{\dagger}$ \\
\hline
\end{tabular}

(table continues) 
Table 4 (continued)

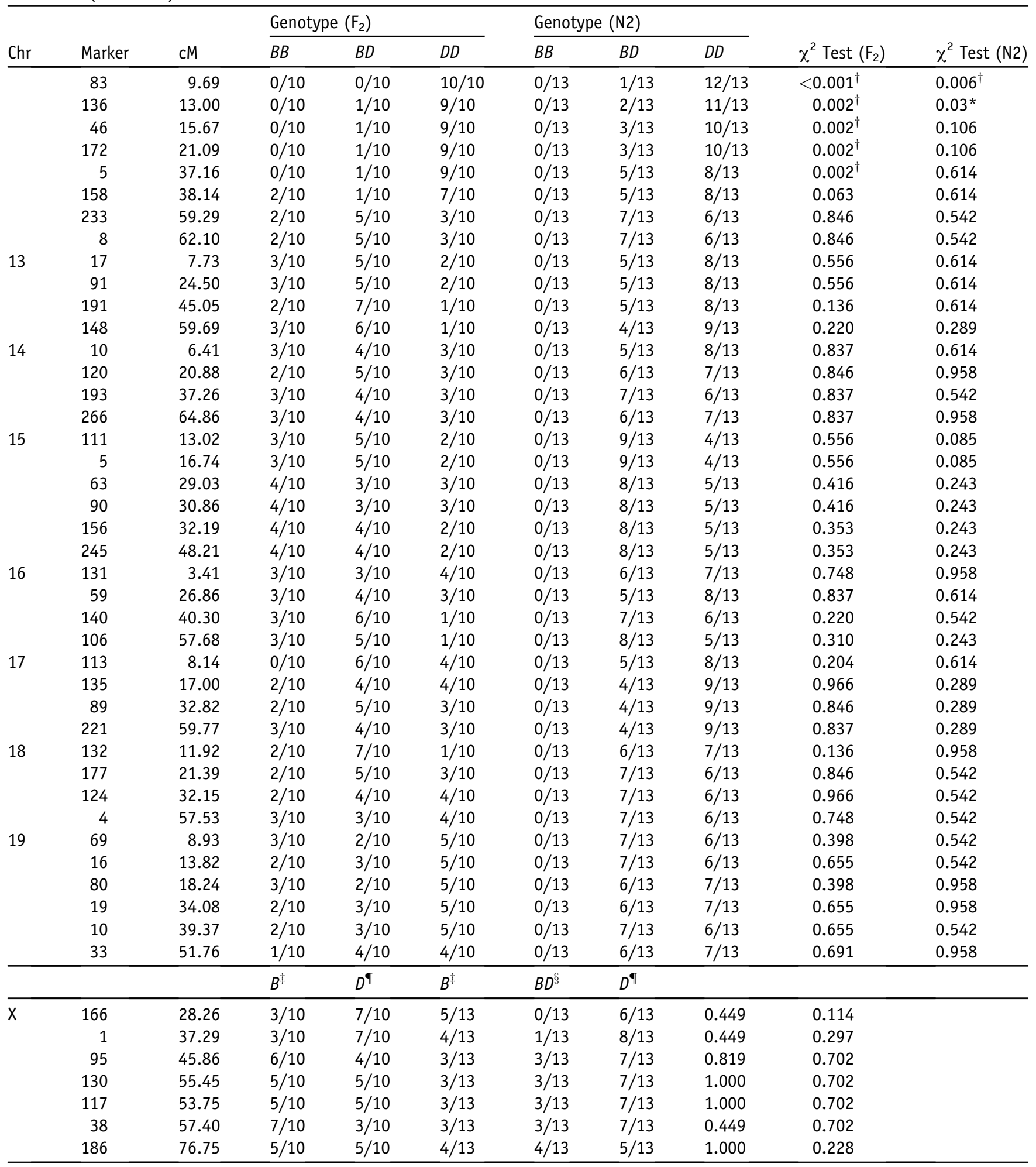

${ }^{*} P<0.05$.

${ }^{\dagger} P<0.01$.

${ }^{\ddagger} \mathrm{C} 57 \mathrm{BL} / 6 \mathrm{~N}$-type male.

${ }^{\S}$ Heterozygote female.

'D2Cr-type male.

$B B, C 57 \mathrm{BL} / 6 \mathrm{~N}$-type homozygote; $B D$, heterozygote; $C h r$, chromosome; $\mathrm{D} 2 \mathrm{Cr}, \mathrm{DBA} / 2 \mathrm{Cr} ; \mathrm{DD}, \mathrm{D} 2 \mathrm{Cr}$ homozygote; $\mathrm{DT}$, distal tubule; $\mathrm{F}_{2},\left(\mathrm{~B}^{\mathrm{N} N} \times \mathrm{D} 2 \mathrm{Cr}\right)\left(\mathrm{BDF} \mathrm{F}_{1}\right) \times$ $\mathrm{BDF}_{1} ; \mathrm{N} 2, \mathrm{BDF}_{1} \times \mathrm{D}_{2} \mathrm{Cr}$. 
A

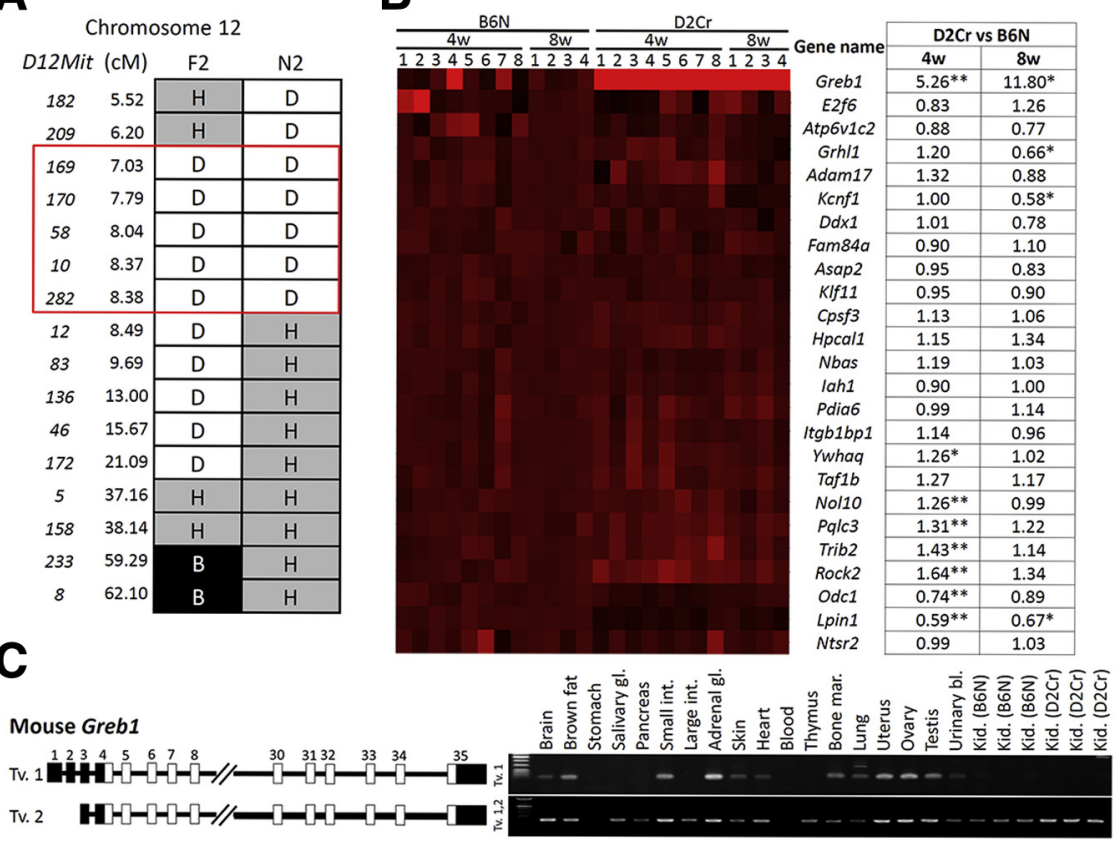

Figure 6 Analysis of drecy locus by using C57BL/6N (B6N) and DBA/2Cr (D2Cr) mice and their progeny. A: Genotype of $\left(\mathrm{B} 6 \mathrm{~N} \times \mathrm{D} 2 \mathrm{Cr} ; \mathrm{BDF}_{1}\right)$ $\times \mathrm{BDF}_{1}\left(\mathrm{~F}_{2}\right)$ and $\mathrm{BDF}_{1} \times \mathrm{D}_{2} \mathrm{Cr}(\mathrm{N} 2)$ progenies showing distal tubule (DT) abnormalities and having a narrower genomic locus compared with drecy, as determined in Table 1. Red box indicates the candidate region in drecy (D12Mit169D12Mit282). B: Gene expression coded on chromosome 12 (D12Mit169-282) in the kidneys. The result of real-time PCR summarized by heat map (left side) and values (right side). Values denote the fold increase compared with $\mathrm{B} 6 \mathrm{~N}$ mice at the same age. A significant difference with $\mathrm{B} 6 \mathrm{~N}$ is indicated. C: Mouse Greb1 gene structure and its expression in the kidney. Left side: Numbers, black boxed areas, and white boxed areas indicate the exon numbers, untranslated regions, and translated regions, respectively. Right side: RTPCR analysis using whole organs. ${ }^{*} P<0.05$, $* * P<0.01$. 4w, 4-week-old mice; 8w, 8-week-old mice; B, B6N type; bl., bladder; D, D2Cr type; gl., gland; $\mathrm{H}$, heterozygote; int., intestine; Kid., kidney; mar., marrow; Tv, transcript variant; $w$, weeks.
Kidneys of D2Cr mice displayed increased expression of Grebl mRNA that was sustained through 24 weeks (Figure7A). The Greb1-positive reaction was observed in the renal cortex rather than in the medulla (Figure 7, B and C), especially in renal tubules and glomeruli (Figure 7D). Of interest, Greb1 localization was mainly cytoplasmic in renal tubules of B6N mice (Figure 7E), whereas Greb1 nuclear localization was observed in $\mathrm{D} 2 \mathrm{Cr}$ mice (Figure 7F). Abnormal renal tubules in $\mathrm{D} 2 \mathrm{Cr}$ mice also showed a Greb1-positive reaction (Figure 7G), indicating DT localization of Greb1. Greb1 was confirmed to be localized to DTs, including the macula densa, by counterstaining with periodic acid-Schiff-hematoxylin, and glomerular podocytes, by double staining with synaptopodin (Figure 7, G-I). The percentage of nuclei showing a Greb1-positive reaction in DTs was significantly higher in $\mathrm{D} 2 \mathrm{Cr}$ mice compared with B6N mice (Figure $7 \mathrm{~J}$ ). An in vitro experiment showed that Grebl overexpression in M-1 cells increased the gene expression of Grebl and vimentin (Vim) and decreased the expressions of $C d 9$ and Cdhl (Figure 7K). Morphologic analysis of Grebl-overexpressing cells revealed a reduced cell size and fusiform cell shape, although the DNA concentration in the medium, which was attributable to detached cells, was not changed (Figure 7, L-N). In the D2Cr mouse kidney, some epithelial cells of abnormal DTs showed weak positive reactions for vimentin, and mononuclear cells in tubulointerstitial lesions also showed strong positive reactions (Figure 7O).

Finally, B6N-based congenic mice carrying the drecy locus, D12Mit182-83, were generated (Figure 8A). Similar to $\mathrm{D} 2 \mathrm{Cr}$, Greb1 expression in the kidney was significantly higher in B6.D2-(D12Mit182-83) congenic mice than in B6N mice, and the expression of ATPase, $\mathrm{H}^{+}$transporting, lysosomal V1 subunit C2 (Atp6v1c2) was also relatively higher in the kidney of $\mathrm{D} 2 \mathrm{Cr}$ mouse than in that of $\mathrm{B} 6 \mathrm{~N}$ mice (Figure 8B). Phenotype analysis of B6.D2(D12Mit182-83) congenic mice revealed DT abnormalities in N6 progeny (homozygotes, $1.6 \%$ of $\mathrm{D} 2 \mathrm{Cr}$ mouse genome) but not in N10 progeny (homozygotes, $0.1 \%$ of D2Cr mouse genome) (Figure 8C). On the other hand, the $\mathrm{F}_{1}$ progeny of $\mathrm{D} 2 \mathrm{Cr}$ and B6.D2-(D12Mit182-83) congenic mice (50.0\% of D2Cr mouse genome) showed DT abnormalities. These results suggest that the development of DT abnormality in $\mathrm{D} 2 \mathrm{Cr}$ mice requires interaction(s) between drecy and another locus (or other loci) in the $\mathrm{D} 2 \mathrm{Cr}$ mouse genome. The abnormal DTs in the $\mathrm{F}_{1}$ progeny of $\mathrm{D} 2 \mathrm{Cr}$ and B6.D2-(D12Mit182-83) congenic mice showed positive reactions for uromodulin and calbindin D28k and an intense reaction of $\mathrm{Na}^{+} / \mathrm{K}^{+}$ATPase at the lateral side of cells (Figure 8D).

Table 5 SNP of Greb1 Exons Associated with the Amino Acid Alternation Between $\mathrm{B} 6 \mathrm{~N}$ and $\mathrm{D} 2 \mathrm{Cr}$

\begin{tabular}{clllll}
\hline Chr start & Chr end & B6N & D2Cr & SNP quality & Alternation \\
\hline 16696556 & 16696556 & C & A & 222 & A1238S \\
16696760 & 16696760 & A & G & 173 & S1170P \\
16696807 & 16696807 & G & A & 165 & A1154V \\
16708727 & 16708727 & C & T & 222 & V663I \\
16723384 & 16723384 & G & T & 159 & P230T \\
\hline
\end{tabular}

Exome analysis.

$\mathrm{B} 6 \mathrm{~N}, \mathrm{C} 57 \mathrm{BL} / 6 \mathrm{~N}$; Chr, chromosome; D2Cr, DBA/2Cr; SNP, singlenucleotide polymorphism. 

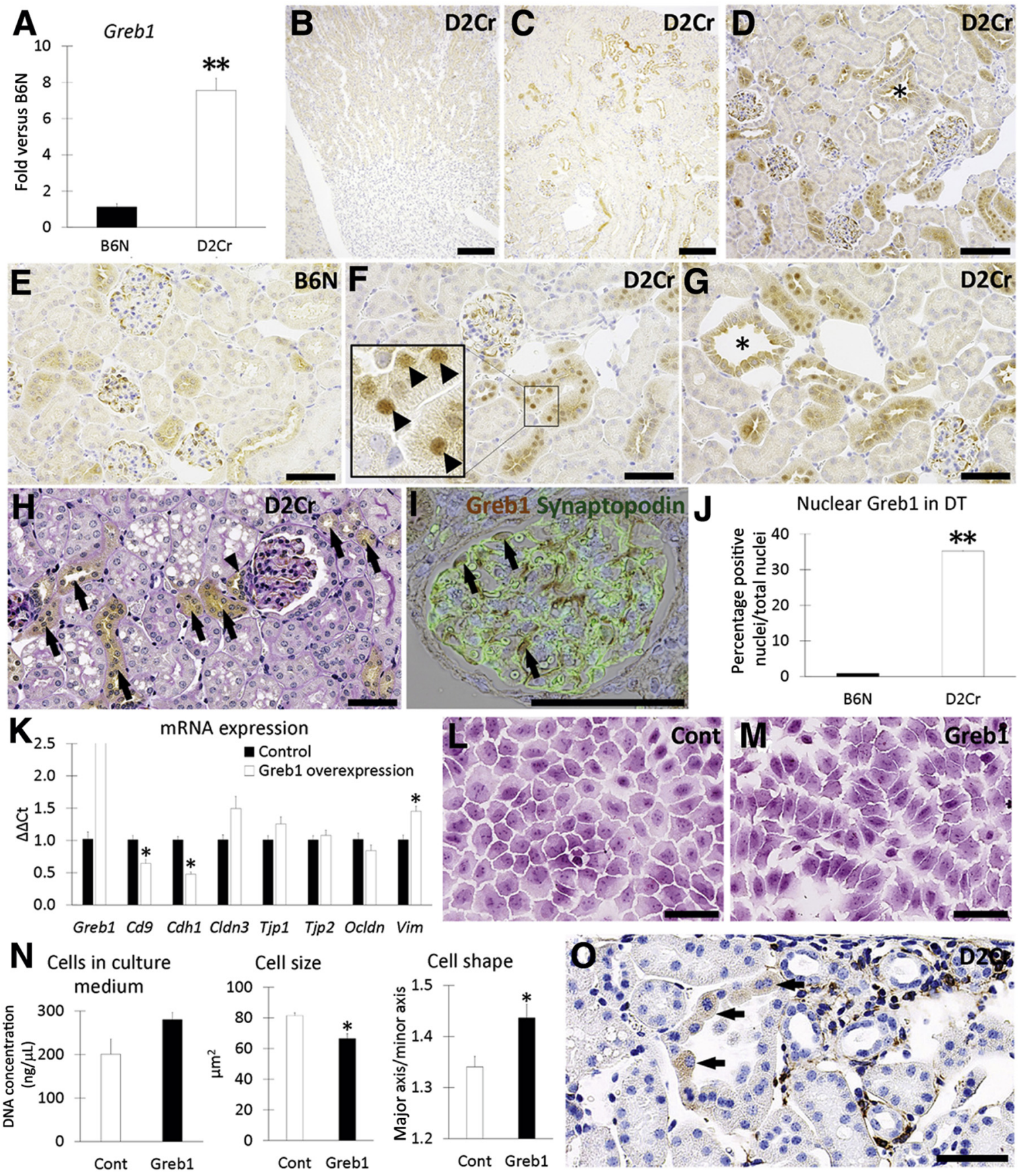

Figure 7 Gene regulated by estrogen in breast cancer protein (Greb1) expression in mouse kidney and in vitro overexpression analysis. A: Gene expression of Greb1 in the kidney at 6 months of age. Real-time PCR results. A significant difference between C57BL/6N (B6N) mice and DBA/2Cr (D2Cr) mice is indicated. B-G: Immunohistochemistry for Greb1 in the kidney at 8 months of age. B and C: Greb1-positive reactions are detected in the cortex, but not in the medulla, of D2Cr mice at 8 months of age. D-G: In the cortex, normal and abnormal distal tubules (DTs; asterisks) as well as glomeruli show positive reactions. $\mathbf{E}$ and F: Nuclear localization is observed in the DT of D2Cr mice (inset and arrowheads; F), but not in B6N mice (E). Inset in F shows a threefold magnification view of the boxed area. H: Immunohistochemistry for Greb1 with periodic acid-Schiff-hematoxylin staining in the kidney at 8 months of age. Greb1-positive reactions evident in the DT (arrows), including the macula densa (arrowhead). I: Double staining for Greb1 (brown) and synaptopodin (green) in the kidney at 8 months of age. Glomerular podocyte (arrows) shows both positive reactions. Nuclei are visualized by Hoechst (blue). J: The percentage of Greb1-positive nuclei in DT. A significant difference between B6N mice and D2Cr mice is indicated. K-N: Analysis of Greb1 overexpression in vitro. K: Gene expression associated with DT morphofunction in mouse M-1 kidney cell line. Real-time PCR. L and M: Compared with control cells (Cont; L), Greb1-overexpressing cells (M) show increased major axis/minor axis with slightly decreased cells sizes. Hematoxylin and eosin staining. N: Morphometrical analysis. A significant difference between control cells and Greb1-overexpressing cells is indicated. 0: Immunohistochemistry for vimentin in the kidneys of D2Cr mice. Vimentin-positive reactions are observed in some epithelial cells of abnormal DTs (arrows) with weak positive reactions, and mononuclear cells in tubulointerstitial lesions also show strongly positive reactions. Data are expressed as means \pm SEM $(\mathbf{A}, \mathbf{J}, \mathbf{K}$, and $\mathbf{N})$. $n=8$ kidneys (A); $n=10$ (J, B6N mice); $n=6$ (J, D2Cr mice); $n=4$ (K and N , cell culture plates). ${ }^{*} P<0.05,{ }^{*} P<0.01$. Scale bars: $200 \mu \mathrm{m}(\mathbf{B}$ and C); $100 \mu \mathrm{m}$ (D); $50 \mu \mathrm{m}$ (E-I, L, M, and $\mathbf{0})$. 


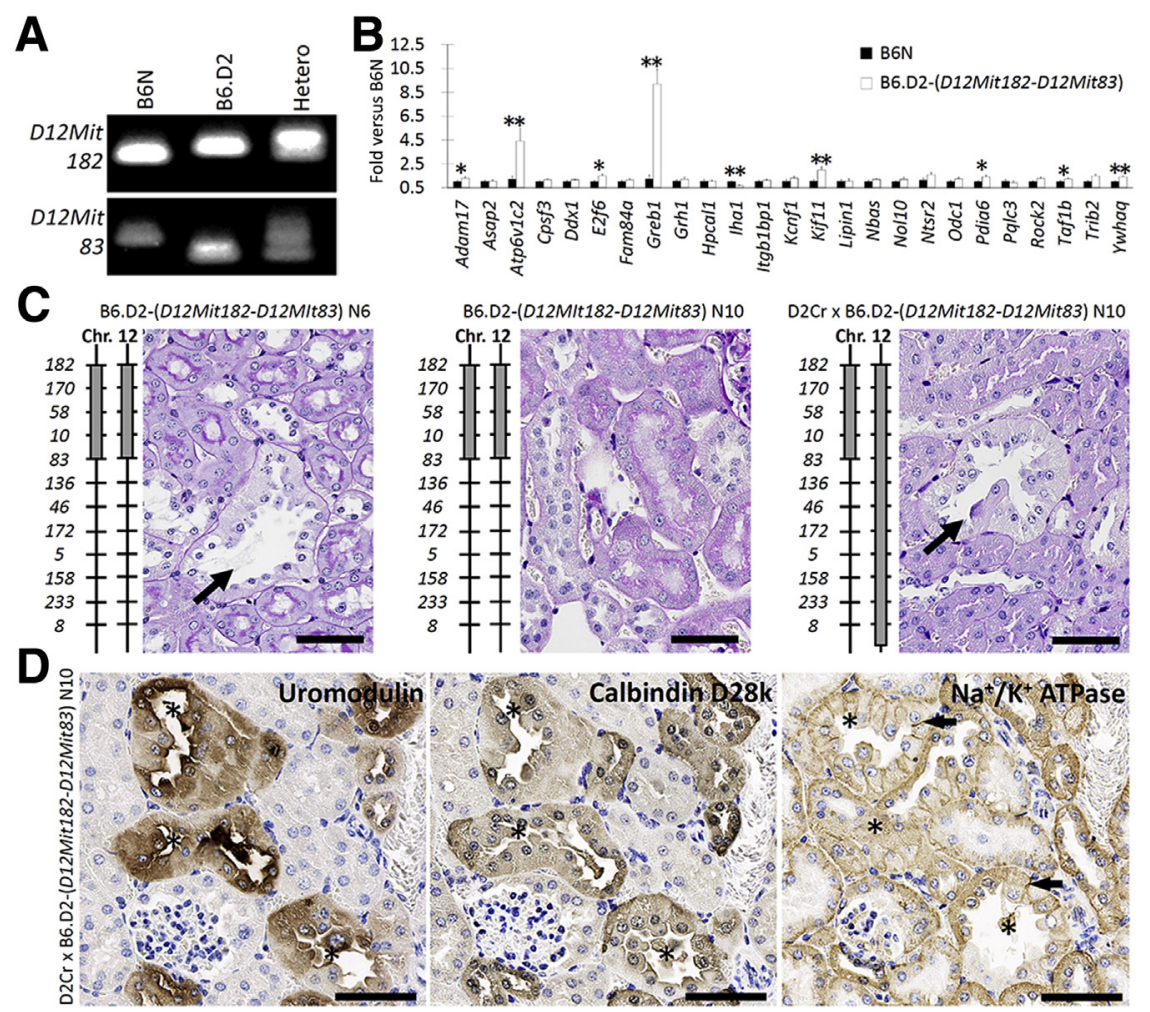

Figure 8 Analysis of congenic mice carrying the DBA/2Cr (D2Cr) -type drecy locus. A: Genotype of D12Mit182 and D12Mit83 flanking drecy locus. Analysis was by PCR. Hetero indicates an individual having both $\mathrm{B} 6 \mathrm{~N}$ - and B6.D2-type genotypes. B: Expression of genes on chromosome (Chr) 12 (D12Mit169-282) in the kidneys at 5 weeks of age, as determined by real-time PCR. A significant difference with $\mathrm{C} 57 \mathrm{BL} / 6 \mathrm{~N}(\mathrm{~B} 6 \mathrm{~N})$ is indicated. C: Genotype of Chr 12 and appearance of abnormal distal tubule (DT) in B6.D2-(D12Mit182-D12Mit83) (B6.D2) congenic mice. Gray boxed areas indicate the D2Cr-type locus. D: Immunohistochemistry for uromodulin, calbindin D28k, $\mathrm{Na}^{+} / \mathrm{K}^{+}$ATPase, and gene regulated by estrogen in breast cancer protein in the kidney of $F_{1}$ progeny of $\mathrm{D} 2 \mathrm{Cr}$ and B6.D2(D12Mit182-83) congenic mice. C: The abnormal DTs (asterisks) in the $\mathrm{F}_{1}$ progeny of $\mathrm{D} 2 \mathrm{Cr}$ and B6.D2-(D12Mit182-83) congenic mice display positive reactions for uromodulin and calbindin D28k and an intense reaction for $\mathrm{Na}^{+} / \mathrm{K}^{+}$ATPase at the lateral side of cells (arrows). Data are expressed as means \pm SEM (B). $n=8$ kidneys (B). ${ }^{*} P<0.05$, ${ }^{*} P<0.01$. Scale bar $=50 \mu \mathrm{m}(\mathbf{C}$ and $\mathbf{D})$.

\section{Discussion}

The renal histopathology of seven inbred mouse strains was examined, and it was found that the $\mathrm{A} / \mathrm{J}, \mathrm{C} 3 \mathrm{H} / \mathrm{He}, \mathrm{DBA} / 1 \mathrm{~J}$, $\mathrm{D} 2 \mathrm{Cr}$, and $\mathrm{FVB} / \mathrm{N}$ mice had similar DT abnormalities characterized by cystic features. Kidney phenotypes associated with these strains have been reported. A/J mice develop renal tumors and small tumors showing cystic lesions lined with multilayered epithelial cells when exposed to the ferric complex of nitrilotriacetic acid. ${ }^{23}$ In addition, $\mathrm{C} 3 \mathrm{H}$ mice are highly susceptible to glucocorticoidinduced newborn PKD compared with DBA mice, ${ }^{24}$ and FVB/N mice are highly susceptible to kidney disease, particularly to experimental glomerulosclerosis. ${ }^{25}$ Thus, each strain has kidney-related phenotypes. However, a common kidney phenotype or a shared genotype associated with kidney abnormalities among these strains has not been described. The DBA/2-type genome has several kidneyrelated phenotypes, including high susceptibility for PKD,${ }^{8-10}$ giant lysosome in PTs,${ }^{11}$ higher albumin excretion, ${ }^{12}$ development of ureteritis-hydronephrosis, ${ }^{13}$ higher kidney calcium concentrations, ${ }^{14}$ and streptozotocininduced diabetic nephropathy. ${ }^{15}$ Although it is possible that the specific genetic factors causing DT abnormality might be shared among A/J, C3H/He, DBA/1J, D2Cr, and FVB/N mice, a global genetic and phenotypic linkage analysis would be needed to clarify this possibility. In this study, D2Cr mice were studied because they had more obviously evident DT abnormalities without sex-related differences compared with the other mouse strains. Furthermore, there is a great deal of knowledge of the genetics of D2Cr mice.

More important, both female and male $\mathrm{D} 2 \mathrm{Cr}$ mice showed the highest DT abnormality scores in the present study. DT abnormalities of D2Cr mice were characterized by columnar epithelial cells, dilated lumens, and age-related progression of cystic lesions. The most unique feature was the limited localization to DTs, including distal tubules that were straight and convoluted. Well-developed abnormal DT was heterogeneous for calbindin D28k, with positive and negative reactions observed. The data indicate the possibilities of altered cell phenotypes or the involvement of calbindin D28k-negative cells in the development of abnormal tubules in D2Cr mice. DT-specific cystic changes of DT are reported to be scarce but are found in distal renal tubular acidosis of human patients ${ }^{26}$ and some types of $\mathrm{NPH}{ }^{27}$ Although proliferative activity in the cells lining renal cysts has been suggested, ${ }^{28}$ in the present study, abnormal DT epithelial cells incorporating BrdU did not increase in number with the progression of abnormality in D2Cr mice, indicating the weak contribution of proliferation to the development of this phenotype. Furthermore, transmission electron microscopy and molecular analyses revealed the altered expression and localization of CD9, E-cadherin, and $\mathrm{Na}^{+} / \mathrm{K}^{+}$ATPase in abnormal DTs in D2Cr mice, indicating the altered morphofunction of DT 
associated with osmotic stress in DTs,${ }^{21}$ cell adhesion, ${ }^{28}$ and cell polarity, ${ }^{29}$ as found in renal cysts in human and animal models. Furthermore, in humans, tight junction proteins, including zonula occludens- 1 and occludin, are also abundantly expressed and correctly localized in renal cysts of PKD, ${ }^{30}$ but these mRNA expressions were presently reduced in kidney tissue of D2Cr mice. DT abnormality of $\mathrm{D} 2 \mathrm{Cr}$ mice was milder compared with the cystic lesions found in the patient and animal models for PKD, distal renal tubular acidosis, or NPH. This was the most prominent difference between known renal cystic features in human and animal models and those in $\mathrm{D} 2 \mathrm{Cr}$ mice. In fact, although data of blood electrolyte balance of B6N, BALB/c, and $\mathrm{D} 2 \mathrm{Cr}$ mice were obtained at 10 and 20 weeks of age $(n=10)$ from the commercial breeder (Japan SLC Inc., Shizuoka, Japan), no related change of electrolytes was noted in D2Cr mice compared with the other two strains of mice that did not display DT abnormality (eg, the respective blood levels of sodium, potassium, and chloride in 20week-old male mice was $151.5,5.17$, and $119.4 \mathrm{mEq} / \mathrm{L}$ in D2Cr mice, respectively; $150.8,4.48$, and $113.4 \mathrm{mEq} / \mathrm{L}$ in B6N mice, respectively; and 152.7, 5.36, and $121.0 \mathrm{mEq} /$ $\mathrm{L}$ in $\mathrm{BALB} / \mathrm{c}$ mice, respectively). Although strain differences were observed, there was no clear tendency between $\mathrm{D} 2 \mathrm{Cr}$ mice and B6N and BALB/c mice. Furthermore, the cystic DTs of D2Cr mice were connected with normal DTs, whereas the cysts that develop in PKD reportedly separate from the original nephron. ${ }^{29}$ Thus, the unique characteristics of renal tubule abnormality were specific localization to DT segments with altered morphofunction associated with cell adhesion and polarity. This phenotype seems to be novel in humans and animals.

The abnormal DT in D2Cr mice expressed IL-36 $\alpha /$ IL-1F6 and displayed expanded primary cilia. These phenotypes have been reported in unilateral ureter obstruction mice. ${ }^{31}$ IL-36 $/$ /IL-1F6 expression in the kidney is associated with tubulointerstitial inflammation (such as immune cell infiltration), cell death, and fibrosis, and can induce the production of IL-6 and protease, serine 35 (Prss35) protease, an inflammatory cytokine, and collagen remodeling-associated enzyme, respectively, in cultured fibroblasts via IL-36 $\alpha / \mathrm{IL}-1 \mathrm{~F} 6$ receptor signaling. ${ }^{31}$ Therefore, IL-36 $\alpha / \mathrm{IL}-1 \mathrm{~F} 6$ from abnormal DTs in D2Cr mice would also participate in the tubulointerstitial pathogenesis. Of importance, unilateral ureter obstruction persisting for 8 days can cause injury and dilation of DTs, accompanied by a significant increase in cilia length. ${ }^{32,33}$ Cilia have receptors and ion channels associated with phototransduction, olfactory sensing, mechanosensing, and extracellular signaling. ${ }^{34}$ Many organs and tissues, including the brain, kidney, liver, pancreas, oviduct, and olfactory cells, also have nonmotile primary cilia that sense the external environment. Functional defect of cilia is termed ciliopathy. PKD or NPH are wellknown kidney-related hereditary ciliopathies. The genetic analysis in the present study revealed that the DT abnormality in D2Cr mice was autosomal recessive, and the candidate locus for DT abnormality in $\mathrm{D} 2 \mathrm{Cr}$ mice was identified on Chr 12 (D12Mit182-D12Mit83) and designated as drecy. In particular, Chr 12 (D12Mit169-D12Mit282) in drecy would encode the candidate genes, but this locus did not contain any cilium-associated genes. Therefore, the morphologic change of primary cilia in DT of D2Cr mice might be a secondary effect attributable to dilations of the DT lumen.

Concerning Atp6v1c2 on Chr 12 (D12Mit169-D12Mit282) in drecy, it was reported that mutations of its gene family in humans, especially ATPase $\mathrm{H}^{+}$transporting V1 subunit B1 (ATP6V1B1), is associated with human distal renal tubular acidosis with sensorineural deafness. ${ }^{35}$ Although Atp6v1c2 expression in the kidney was significantly higher in B6.D2(D12Mit182-D12Mit83) congenic mice than in B6N mice, the expression was similar between $\mathrm{B} 6 \mathrm{~N}$ and $\mathrm{D} 2 \mathrm{Cr}$ mice, and there was no common single-nucleotide polymorphism of Atp6v1c2 among DT abnormality-prone strains $(\mathrm{A} / \mathrm{J}, \mathrm{C} 3 \mathrm{H} /$ HeJ, DBA/1J, DBA/2J, and FVB/NJ) examined in the Mouse Phenome Database (https://phenome.jax.org, last accessed January 12, 2018). On the other hand, Grebl expression in the kidney was remarkably higher in $\mathrm{D} 2 \mathrm{Cr}$ mice compared with B6N mice at 4, 8, and 24 weeks, and five singlenucleotide polymorphisms associated with an amino acid substitution were identified between these strains. Interestingly, Greb1 protein is localized to the DT cytoplasm in B6N mice, but in the cytoplasm and nucleus in D2Cr mice. The differences associated with the expression level, amino acid sequence, and protein localization of Greb1 might strongly affect the development of DT abnormality compared with other genes on drecy.

Recent studies showed that the mutation of growth regulation by estrogen in breast cancer 1-like associated with congenital kidney malformations in humans and mice. ${ }^{36,37}$ However, the relationship between Greb1 and the kidney is unknown. Greb1 is considered to play important roles in sex hormone-responsive tissues and cancers, such as breast and prostate cancer. ${ }^{38,39}$ A female-dominant DT abnormality was noted in $\mathrm{C} 3 \mathrm{H} / \mathrm{He}$ mice. However, this sexrelated phenotype was not evident in $\mathrm{D} 2 \mathrm{Cr}$ mice in the present study. On the other hand, a recent study revealed that Greb1 regulates tissue morphogenesis, in particular convergent extension, during zebrafish development. ${ }^{40}$ Interestingly, the expression levels of Tv1 and Tv2 of Greb1 differed among organs, and Tv2-dominant expression was detected in the mouse kidney. Furthermore, Grebloverexpressing M-1 cells displayed an altered gene expression balance associated with the epitheliummesenchyme phenotype with morphologic changes. Therefore, the elevated and organ-specific Tv expression of Grebl might be associated with DT abnormality attributable to altered cell behaviors, such as cell proliferation, and epithelial-mesenchyme phenotypes. However, B6.D2(D12Mit182-D12Mit83) N10 congenic mice did not display DT abnormality, whereas D2Cr $\times$ B6.D2- $($ D12Mit182D12Mit83) N10 mice did. The latter harbor a D2Cr-type 
homogeneous drecy locus and heterogeneous genotype derived from $\mathrm{B} 6 \mathrm{~N}$ and $\mathrm{D} 2 \mathrm{Cr}$. Inbred mice, including the DBA/2 strain, have several modifier genes of renal cystic phenotypes on Chr $1,2,4,10,16$, or $19 .^{7-10}$ Therefore, in addition to the main candidate gene on drecy, including Greb1, the interactions from other genes would be needed to fully develop the DT abnormality in mice.

The genetic region of mouse chromosome 12 containing drecy is strongly homologous to human chromosome 2 (2p25.1). Although human chromosome 2 contains several kidney disease-associated loci, such as NPHP on $2 \mathrm{q} 12$ $\mathrm{q} 13,{ }^{41,42}$ and renal anomalies on $2 \mathrm{p} 15$ and $\mathrm{p} 16,{ }^{43}$ there is no report for $2 \mathrm{p} 25.1$. We identified a novel DT abnormality characterized by aging-related renal cystic changes with altered molecular expression associated with DT morphofunction in $\mathrm{D} 2 \mathrm{Cr}$ mice. This phenotype was regulated by the D2Cr-derived drecy locus on chromosome 12.

However, an important limitation of this study is that the functions of candidate genes within the drecy region remain unclear. In future studies, the candidate gene, especially focusing on Greb1, and the interactive effects from the other unknown genes should be examined to clarify the molecular basis of this novel phenotype.

\section{Acknowledgments}

O.I. conceived and performed experiments and analyzed data; O.I., T.N., T.H., Y.H.A.E., and Y.K. conceived experiments; A.Y. provided mouse samples; and all authors wrote the article and approved the final manuscript.

\section{References}

1. Wu M, Yu S: New insights into the molecular mechanisms targeting tubular channels/transporters in PKD development. Kidney Dis 2016, 2:128-135

2. Slaats GG, Lilien MR, Giles RH: Nephronophthisis: should we target cysts or fibrosis? Pediatr Nephrol 2016, 31:545-554

3. Braun DA, Hildebrandt F: Ciliopathies. Cold Spring Harb Perspect Biol 2017, 9:a028191

4. Horibe H, Fujimaki T, Oguri M, Kato K, Matsuoka R, Abe S, Tokoro F, Arai M, Noda T, Watanabe S, Yamada Y: Association of a polymorphism of the interleukin 6 receptor gene with chronic kidney disease in Japanese individuals. Nephrology 2015, 20:273-278

5. Hayek SS, Koh KH, Grams ME, Wei C, Ko Y-A, Li J, Samelko B, Lee H, Dande RR, Lee HW, Hahm E, Peev V, Tracy M, Tardi NJ, Gupta V, Altintas MM, Garborcauskas G, Stojanovic N, Winkler CA, Lipkowitz MS, Tin A, Inker LA, Levey AS, Zeier M, Freedman BI, Kopp JB, Skorecki K, Coresh J, Quyyumi AA, Sever S, Reiser J: A tripartite complex of suPAR, APOL1 risk variants and $\alpha \mathrm{v} \beta 3$ integrin on podocytes mediates chronic kidney disease. Nat Med 2017, 23:945-953

6. Mao S, Yan B, Zhang J: Association of transforming growth factor- $\beta 1$ polymorphisms with the risk of chronic kidney diseases. Ren Fail 2015, 37:304-311

7. Upadhya P, Churchill G, Birkenmeier EH, Barker JE, Frankel WN: Genetic modifiers of polycystic kidney disease in intersubspecific KAT2J mutants. Genomics 1999, 58:129-137

8. Nagao S, Hibino T, Koyama Y, Marunouchi T, Konishi H, Takahashi H: Strain difference in expression of the adult-type polycystic kidney disease gene, pcy, in the mouse. Jikken Dobutsu 1991, 40:45-53

9. Olbrich H, Fliegauf M, Hoefele J, Kispert A, Otto E, Volz A, Wolf MT, Sasmaz G, Trauer U, Reinhardt R, Sudbrak R, Antignac C, Gretz N, Walz G, Schermer B, Benzing T, Hildebrandt F, Omran H: Mutations in a novel gene, NPHP3, cause adolescent nephronophthisis, tapeto-retinal degeneration and hepatic fibrosis. Nat Genet 2003, 34: 455-459

10. Iakoubova OA, Dushkin H, Beier DR: Localization of a murine recessive polycystic kidney disease mutation and modifying loci that affect disease severity. Genomics 1995, 26:107-114

11. Yabuki A, Matsumoto M, Nishinakagawa H, Suzuki S: Giant lysosomes in the renal proximal tubules: a morphological characteristic of DBA/2 and DBA/1 mouse kidneys. Exp Anim 2003, 52:159-163

12. Sheehan S, Tsaih S-W, King BL, Stanton C, Churchill GA, Paigen B, DiPetrillo K: Genetic analysis of albuminuria in a cross between C57BL/6J and DBA/2J mice. AJP Ren Physiol 2007, 293: F1649-F1656

13. Ichii O, Otsuka S, Namiki Y, Hashimoto Y, Kon Y: Molecular pathology of murine ureteritis causing obstructive uropathy with hydronephrosis. PLoS One 2011, 6:e27783

14. van den Broek FAR, Beynen AC: Effect of dietary fat level on the calcium content of heart and kidney in DBA/2 and C57BL/6 mice. Lab Anim 1998, 32:206-213

15. Gurley SB: Impact of genetic background on nephropathy in diabetic mice. AJP Ren Physiol 2005, 290:F214-F222

16. Mozes E, Alling D, Miller MW, Payne SM, Zinger H, Via CS, Shearer GM: Genetic analysis of experimentally induced lupus in mice. Clin Immunol Immunopathol 1997, 85:28-34

17. Ichii $\mathrm{O}$, Chihara $\mathrm{M}$, Lee $\mathrm{S}-\mathrm{H}$, Nakamura $\mathrm{T}$, Otsuka-Kanazawa $\mathrm{S}$, Horino T, Elewa YHA, Kon Y: Hydronephrosis with ureteritis developed in $\mathrm{C} 57 \mathrm{BL} / 6 \mathrm{~N}$ mice carrying the congenic region derived from MRL/Mpj-type chromosome 11. Autoimmunity 2017, 50: $114-124$

18. Ichii O, Otsuka S, Sasaki N, Yabuki A, Ohta H, Takiguchi M, Hashimoto Y, Endoh D, Kon Y: Local overexpression of interleukin-1 family, member 6 relates to the development of tubulointerstitial lesions. Lab Invest 2010, 90:459-475

19. Ichii O, Konno A, Sasaki N, Endoh D, Hashimoto Y, Kon Y: Autoimmune glomerulonephritis induced in congenic mouse strain carrying telomeric region of chromosome 1 derived from MRL/Mpj. Histol Histopathol 2008, 23:411-422

20. Shiozuru D, Ichii O, Kimura J, Nakamura T, Elewa YH, OtsukaKanazawa S, Kon Y: MRL/MpJ mice show unique pathological features after experimental kidney injury. Histol Histopathol 2016, 31: 189-204

21. Sheikh-Hamad D, Youker K, Truong LD, Nielsen S, Entman ML: Osmotically relevant membrane signaling complex: association between Hb-Egf, beta(1)-integrin, and CD9 in mTAL. Am J Physiol Cell Physiol 2000, 279:C136-C146

22. Wilson PD: Apico-basal polarity in polycystic kidney disease epithelia. Biochim Biophys Acta 2011, 1812:1239-1248

23. Li JL, Okada S, Hamazaki S, Ebina Y, Midorikawa O: Subacute nephrotoxicity and induction of renal cell carcinoma in mice treated with ferric nitrilotriacetate. Cancer Res 1987, 47:1867-1869

24. Ogborn MR, Crocker JF: Ontogeny of dexamethasone binding and sodium potassium atpase activity in experimental murine polycystic kidney disease. J Steroid Biochem Mol Biol 1991, 39:181-184

25. Sasaki H, Marusugi K, Kimura J, Kitamura H, Nagasaki K-I, Torigoe D, Agui T, Sasaki N: Genetic background-dependent diversity in renal failure caused by the tensin 2 gene deficiency in the mouse. Biomed Res 2015, 36:323-330

26. Igarashia $\mathrm{T}$, Kosugih $\mathrm{T}$ : The incidence of renal cyst formation in patients with primary distal renal tubular acidosis. Nephron 1994, 66:474

27. Takada D, Sekine A, Yabuuchi J, Kogure Y, Ueno T, Yamanouchi M, Sumida K, Suwabe T, Hayami N, Hoshino J, Takaichi K, Kinowaki K, 
Fujii T, Ohashi K, Mori T, Sohara E, Uchida S, Ubara Y: Renal histology and MRI in a 25-year-old Japanese man with nephronophthisis 4. Clin Nephrol 2018, 89:223-228

28. Shibazaki S, Yu Z, Nishio S, Tian X, Thomson RB, Mitobe M, Louvi A, Velazquez H, Ishibe S, Cantley LG, Igarashi P, Somlo S: Cyst formation and activation of the extracellular regulated kinase pathway after kidney specific inactivation of Pkd1. Hum Mol Genet 2008, 17:1505-1516

29. Kolb RJ, Nauli SM: Ciliary dysfunction in polycystic kidney disease: an emerging model with polarizing potential. Front Biosci 2008, 13: $4451-4466$

30. Yu A, Kanzawa S, Usorov A, Lantinga-van Leeuwen I, Peters D: Tight junction composition is altered in the epithelium of polycystic kidneys. J Pathol 2008, 216:120-128

31. Ichii O, Kimura J, Okamura T, Horino T, Nakamura T, Sasaki H, Elewa YHA, Kon Y: IL-36 $\alpha$ regulates tubulointerstitial inflammation in the mouse kidney. Front Immunol 2017, 8:1346

32. Verghese E, Weidenfeld R, Bertram JF, Ricardo SD, Deane JA: Renal cilia display length alterations following tubular injury and are present early in epithelial repair. Nephrol Dial Transplant 2008, 23:834-841

33. Wang L, Weidenfeld R, Verghese E, Ricardo SD, Deane JA: Alterations in renal cilium length during transient complete ureteral obstruction in the mouse. J Anat 2008, 213:79-85

34. Park JH, Woo YM, Ko JY, Kim DY: Autosomal dominant polycystic kidney disease induced by ciliary defects. Edited by Li X: Polycystic Kidney Disease, Chapter 15. Brisbane, Australia: Codon Publications, 2015. pp. 375-396

35. Kumar PS, Venkatesh K, Sowjenya G, Srikanth L, Sunitha MM, Prasad UV, Swarupa V, Yeswanth S, Naveen PSR, Sridhar A, Kumar VS, Sarma PVGK: Mutations in exons 3 and 7 resulting in truncated expression of human ATP6V1B1 gene showing structural variations contributing to poor substrate binding-causative reason for distal renal tubular acidosis with sensorineural deafness. J Biomol Struct Dyn 2015, 33:2094-2103

36. De Tomasi L, David P, Humbert C, Silbermann F, Arrondel C, Tores F, Fouquet S, Desgrange A, Niel O, Bole-Feysot C, Nitschké P,
Roume J, Cordier M-P, Pietrement C, Isidor B, Khau Van Kien P, Gonzales M, Saint-Frison M-H, Martinovic J, Novo R, Piard J, Cabrol C, Verma IC, Puri R, Journel H, Aziza J, Gavard L, SaidMenthon M-H, Heidet L, Saunier S, Jeanpierre C: Mutations in GREB1L cause bilateral kidney agenesis in humans and mice. Am J Hum Genet 2017, 101:803-814

37. Sanna-Cherchi S, Khan K, Westland R, Krithivasan P, Fievet L, Rasouly HM, et al: Exome-wide association study identifies GREB1L mutations in congenital kidney malformations. Am J Hum Genet 2017, 101:789-802

38. Mohammed H, D'Santos C, Serandour AA, Ali HR, Brown GD, Atkins A, Rueda OM, Holmes KA, Theodorou V, Robinson JLL, Zwart W, Saadi A, Ross-Innes CS, Chin S-F, Menon S, Stingl J, Palmieri C, Caldas C, Carroll JS: Endogenous purification reveals GREB1 as a key estrogen receptor regulatory factor. Cell Rep 2013, 3:342-349

39. Rae JM, Johnson MD, Cordero KE, Scheys JO, Larios JM, Gottardis MM, Pienta KJ, Lippman ME: GREB1 is a novel androgenregulated gene required for prostate cancer growth. Prostate 2006, 66: 886-894

40. Li S-Z, Liu W, Li Z, Li W-H, Wang Y, Zhou L, Gui JF: Greb1 regulates convergent extension movement and pituitary development in zebrafish. Gene 2017, 627:176-187

41. Hildebrandt F, Singh-Sawhney I, Schnieders B, Centofante L, Omran H, Pohlmann A, Schmaltz C, Wedekind H, Schubotz C, Antignac C, Weber JL, Brandis M; APN Study Group: Mapping of a gene for familial juvenile nephronophthisis: refining the map and defining flanking markers on chromosome 2. Am J Hum Genet $1993,53: 1256-1261$

42. Omran H, Häffner $\mathrm{K}$, Burth $\mathrm{S}$, Ala-Mello S, Antignac C, Hildebrandt F: Evidence for further genetic heterogeneity in nephronophthisis. Nephrol Dial Transplant 2001, 16:755-758

43. Hucthagowder V, Liu TC, Paciorkowski AR, Thio LL, Keller MS, Anderson CD, Herman T, Dehner LP, Grange DK, Kulkarni S: Chromosome 2p15p16.1 microdeletion syndrome: $2.5 \mathrm{Mb}$ deletion in a patient with renal anomalies, intractable seizures and a choledochal cyst. Eur J Med Genet 2012, 55:485-489 